\title{
Geoarchaeological insights into the location of Indus settlements on the plains of northwest India
}

\author{
Sayantani Neogi ${ }^{\mathrm{a}, \mathrm{b}}$, Charles A.I. French ${ }^{\mathrm{a}, \mathrm{c}}$, Julie A. Durcan ${ }^{\mathrm{d}}$, Ravindra N. Singh ${ }^{\mathrm{e}}$, Cameron A. Petrie ${ }^{\mathrm{a}, \mathrm{c} *}$ (I) \\ ${ }^{a}$ McDonald Institute for Archaeological Research, University of Cambridge, Cambridge CB2 3ER, United Kingdom \\ ${ }^{\mathrm{b}}$ Department of Archaeology, Durham University, South Road, Durham DH1 3LE, United Kingdom \\ ${ }^{c}$ Department of Archaeology, University of Cambridge, Downing Street, Cambridge CB2 3DZ, United Kingdom \\ ${ }^{\mathrm{d} S}$ School of Geography and the Environment, University of Oxford, Oxford OX1 3QY, United Kingdom \\ ${ }^{\mathrm{e}}$ Department of AIHC and Archaeology, Banaras Hindu University, Varanasi 221005, India \\ *Corresponding author e-mail address: cap59@ cam.ac.uk (C.A. Petrie).
}

(RECEIVED October 16, 2018; ACCEPTED October 9, 2019)

\begin{abstract}
This article presents a geomorphological and micromorphological study of the locational context of four Indus civilisation archaeological sites-Alamgirpur, Masudpur I and VII, and Burj-all situated on the Sutlej-Yamuna interfluve in northwest India. The analysis indicates a strong correlation between settlement foundation and particular landscape positions on an extensive alluvial floodplain. Each of the analysed sites was located on sandy levees and/or riverbank deposits associated with former channels. These landscape positions would have situated settlements above the level of seasonal floodwater resulting from the Indian summer monsoon. In addition, the sandy soils on the margins of these elevated landscape positions would have been seasonally replenished with water, silt, clay, and fine organic matter, considerably enhancing their capacity for water retention and fertility and making them particularly suitable for agriculture. These former landscapes are obscured by recent modification and extensive agricultural practices. These geoarchaeological evaluations indicate that there is a hidden landscape context for each Indus settlement. This specific type of interaction between humans and their local context is an important aspect of Indus cultural adaptations to diverse, variable, and changing environments.
\end{abstract}

Keywords: Geoarchaeology; Micromorphology; Indus civilisation; Landscapes; Luminescence dating

\section{INTRODUCTION}

The rise of early cities and states in ancient Egypt and Mesopotamia is interwoven with the proximity of the floodplains and associated landforms of major perennial rivers. South Asia's Indus civilisation is also typically regarded as being riverine as the cities and settlements of its urban phase (ca. 2500-1900 BC) were distributed throughout much of the Indus River basin, which is watered by the Indus River and the five major rivers of Punjab. The Nile, TigrisEuphrates, and Indus River basins are all extensive, but it is arguable that of the three, the Indus River basin is the most complex in terms of hydrology and geomorphology. The settlements of the Indus civilisation were distributed across a

Cite this article: Neogi, S., French, C. A. I., Durcan, J. A., Singh, R. N., Petrie, C. A. 2020. Geoarchaeological insights into the location of Indus settlements on the plains of northwest India. Quaternary Research 94, 137-155. https://doi.org/10.1017/qua.2019.70 region that is distinctive in having considerable climatic and ecological diversity, in part because the Indus River basin straddles an environmental threshold where winter and summer rainfall systems overlap, and each has steep gradients (Fig. 1; Petrie et al., 2017, 2018; Petrie and Weeks, 2019). The distribution of the rainfall from these systems combined with the proximity of the Himalayas to the north, the Suleiman Range to the west, and the Thar Desert to the east place a range of constraints on the hydrology and geomorphology of the intermontane valleys and floodplains of the Indus River basin, which in turn affected the ways Indus civilisation populations inhabited this landscape (Petrie, 2017; Petrie et al., 2017, 2018).

Between 2008 and 2014, the collaborative Land, Water and Settlement project investigated long-term human and environment relationships on the plains of northwest India. These extensive plains are composed of the interfluve between the Sutlej and Yamuna Rivers and include the course (or courses) of a major palaeochannel that has 


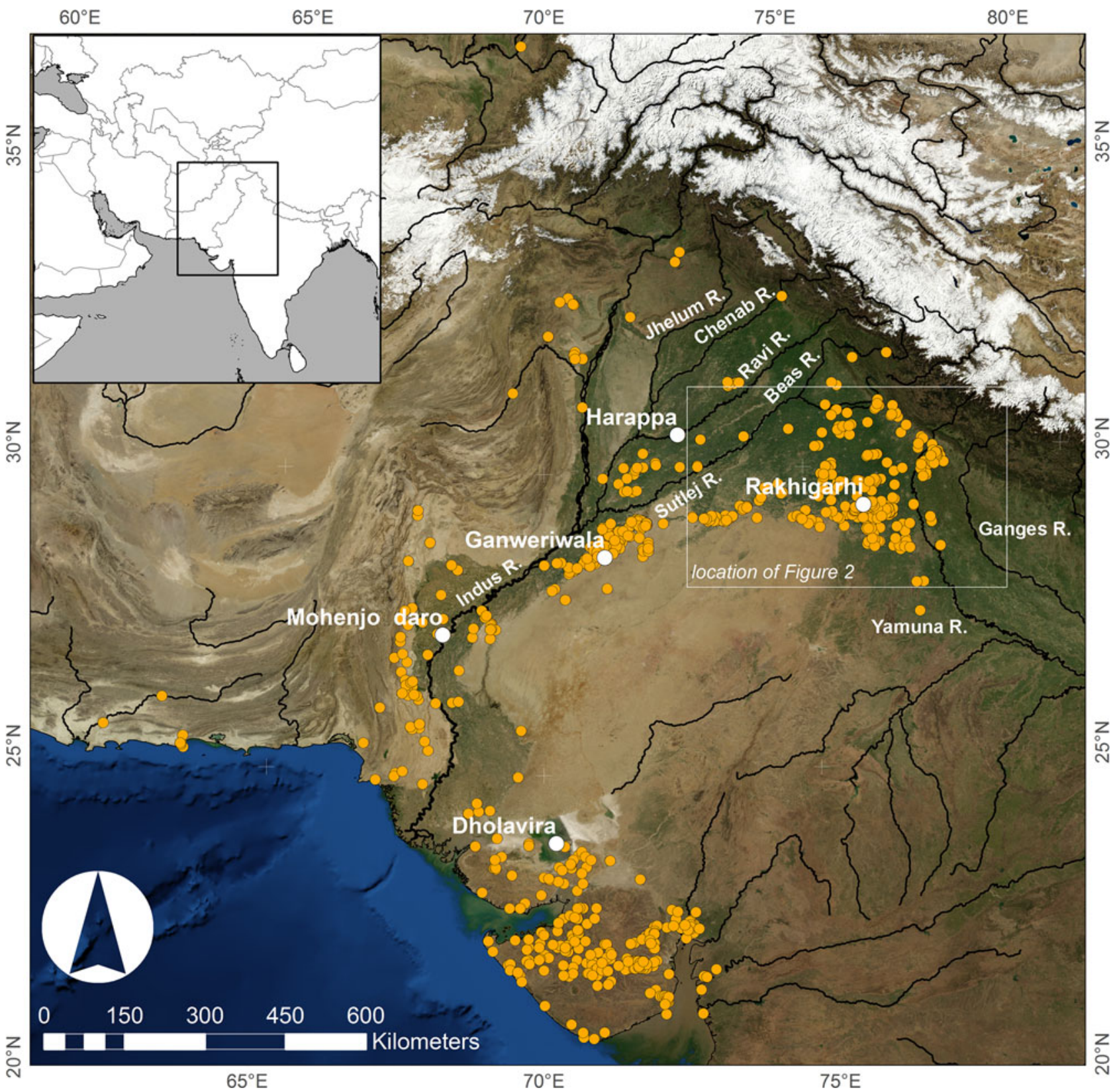

Figure 1. (colour online) Map showing the distribution of settlements dating to the urban phase of the Indus civilisation, including Harappa and Mohenjo Daro, and the modern courses of the major rivers of the Indus River basin (after Petrie, 2017).

been the focus of various research efforts and is often linked to the distribution of Indus civilisation settlements in the region (e.g., Lal, 2002; Valdiya, 2002; Saini et al., 2009; Danino, 2010; Clift et al., 2012; Giosan et al., 2012; Singh et al., 2017). The Land, Water and Settlement project carried out a combination of extensive archaeological survey and integrated geoarchaeological analysis that demonstrated that there is not a simple correlation between visible palaeochannels and settlement location during the Indus period (Petrie et al., 2017; also Singh et al., 2008, 2009, 2010a, 2010b, 2011, 2012, 2013, 2015a, 2015b, 2018; Petrie et al., 2009, 2016, 2018). This article presents a geoarchaeological analysis of the location of four rural Indus civilisation settlements situated in the distinctive alluvial environment of this region. It provides insights into the nature and chronology of landscape morphology and development, soil formation, and the types of decisions influencing populations establishing new settlements in a complex and changing alluvial environment. The analysis presented here suggests that the practices of Indus farmers were well adapted to a dynamic floodplain environment, with limited perennial water availability on the surface. When establishing new settlements, Indus populations made choices that took consideration of elevation, water access, and drainage that assured the agricultural sustainability of those settlements and also aided their resilience to a mid-Holocene climate that was variable (synchronically) within and between years and changing (diachronically) over time. 


\section{HYDROLOGY, GEOARCHAEOLOGY, AND THE INDUS CIVILISATION}

During the urban phase of South Asia's Indus civilisation (ca. 2600/2500-1900 BC), settlements were distributed across an extensive area of the Indus River basin, which stretches across much of modern Pakistan and parts of western India (e.g., Wheeler, 1968; Lal, 1997; Kenoyer, 1998; Chakrabarti, 1999; Possehl, 1999, 2002; Agrawal, 2007; Wright, 2010; Petrie, 2013). This extensive region is made up of a range of climate zones and geomorphological units, with the northern areas primarily being composed of the fertile alluvial plains adjacent to the Indus and the five rivers of Punjab, which stretch to the Ganges-Yamuna catchment to the east (Fig. 1).

There has been a long history of research into the hydrology and associated geomorphology of the Indus River basin, which has focused on both active rivers (e.g., Oldham, 1893; Pilgrim, 1919; Pascoe, 1920; Fraser, 1958; Mithal, 1968; Schroder, 1993; Meadows and Meadows, 1999) and a number of major dried river channels. Palaeochannels were initially recognised on the ground in the nineteenth century (e.g., Oldham, 1874, 1893; Oldham, 1886), subsequently investigated using remote sensing imagery (e.g., Ghose et al., 1979; Yashpal et al., 1980; Ramasamy et al., 1991; Gupta et al., 2004; Bhadra et al., 2009), and, more recently, reconstructed through combinations of remote sensing, coring, provenience analysis, and absolute dating (e.g., Bhadra et al., 2009; Saini et al., 2009; Gupta et al., 2011; Clift et al., 2012; Giosan et al., 2012; van Dijk et al., 2016; Orengo and Petrie, 2017, 2018; Singh et al., 2017). The presence of these palaeochannels suggests that these floodplains are highly dynamic, which has major ramifications for human settlement.

The investigation of the relationship between hydrologic features and Indus civilisation settlements also has a protracted history with most attention being devoted to the environmental settings and site formation of the major urban sites of Mohenjo-Daro (e.g., Raikes, 1964; Lambrick, 1967; Flam, 1981, 1993, 1999, 2013; Cucarzi, 1984, 1987; Raikes and Dales, 1986; Balista, 1988; Leonardi, 1988; Jorgensen et al., 1993; Harvey and Schumm, 1999; Jansen, 1999) and Harappa (e.g., Amundson and Pendall, 1991; Belcher, 1997, 1998; Belcher and Belcher, 2000; Schuldenrein, 2002; Schuldenrein et al., 2004, 2007; Wright, 2010). The analysis at these two city sites has been carried out at relatively high resolution and has detailed the specific relationship between evolving urban settlements and their distinctive and changing local landscapes.

Indus settlements were situated in a range of climatically, ecologically, and environmentally distinct locations, including intermontane valleys, on alluvial fans, at the margins or inside what are today arid zones, in areas that lack perennial rivers but are watered by monsoon rainfall, and even on islands (Wright, 2010, pp. 33-38; Petrie and Thomas, 2012; Petrie, 2013, 2017; Petrie et al., 2017). It has been argued that Indus farmers were well adapted to diverse and variable environments, and that this helped them be resilient to climate change (Petrie, 2017; Petrie et al., 2017), but geoarchaeological characterisation of settlements has only been attempted in some of these contexts. In Gujarat, there is evidence for a number of settlements on sand dunes, and the relationship between these settlements and the interdune areas suited for agricultural exploitation has been explored in some detail (e.g., Balbo et al., 2013; Conesa et al., 2014, 2015, 2017).

In the context of the Indus civilisation, understanding the relationship between settlements and dynamic floodplains is particularly significant, and the relationship between former palaeochannels and archaeological settlement distribution has been examined in Sind (e.g., Flam, 1981, 1993, 2013; Jorgensen et al., 1993), Cholistan (e.g., Stein, 1942; Mughal, 1997; also Geyh and Ploethner, 1995), and the ancient Beas (Schuldenrein, 2002; Schuldenrein et al., 2004, 2007; Wright and Hritz, 2013) in Pakistan, and northern Rajasthan (e.g., Raikes, 1967; Rajani and Rajawat, 2011) and Haryana in northwest India (e.g., Courty, 1985, 1990, 1995; Courty et al., 1987, 1989). However, with the exception of the work along the Beas, much of this analysis been conducted at a large scale and has not involved detailed geoarchaeological analysis at specific archaeological settlements.

\section{THE INDUS CIVILISATION AND THE ALLUVIAL FLOODPLAINS OF NORTHWEST INDIA}

There were relatively few Indus settlements large enough to be regarded as cities, and each of these was situated in a different hydrologic zone and ecological context. One of these large settlements, the Indus city at Rakhigarhi (Nath, 1998; Shinde et al., 2013, 2018), was situated in the central part of the extensive alluvial interfluve that lies between the Sutlej, which is the easternmost of the Punjab rivers, and the Yamuna, which is the westernmost of the major Gangetic rivers (Fig. 1). Today, this extensive plain lacks perennial rivers, but there is evidence that it has been traversed by a substantial number of ephemeral watercourses, some of which appear to have been relatively large palaeochannels (van Dijk et al., 2016; Orengo and Petrie, 2017, 2018).

Today the Sutlej-Yamuna interfluve is an area where winter and summer rainfall systems overlap, and it is characterised by considerable variability and steep gradients in rainfall distribution, such that areas to the west and south receive little direct rainfall, whereas moving to the east and north, areas receive increasing amounts of summer rain, and in the north in particular, also winter rain (Petrie, 2017; Petrie et al., 2017). A number of archaeological survey and excavation projects have demonstrated that the alluvial plains of the Sutlej-Yamuna interfluve in northwestern India were occupied throughout the late prehistoric and historic periods, including extensive occupation by Indus civilisation populations (e.g., Bhan, 1975; Bhan and Shaffer, 1982; Joshi et al., 1984; Possehl, 1999; Chakrabarti and Saini, 2009; Dangi, 


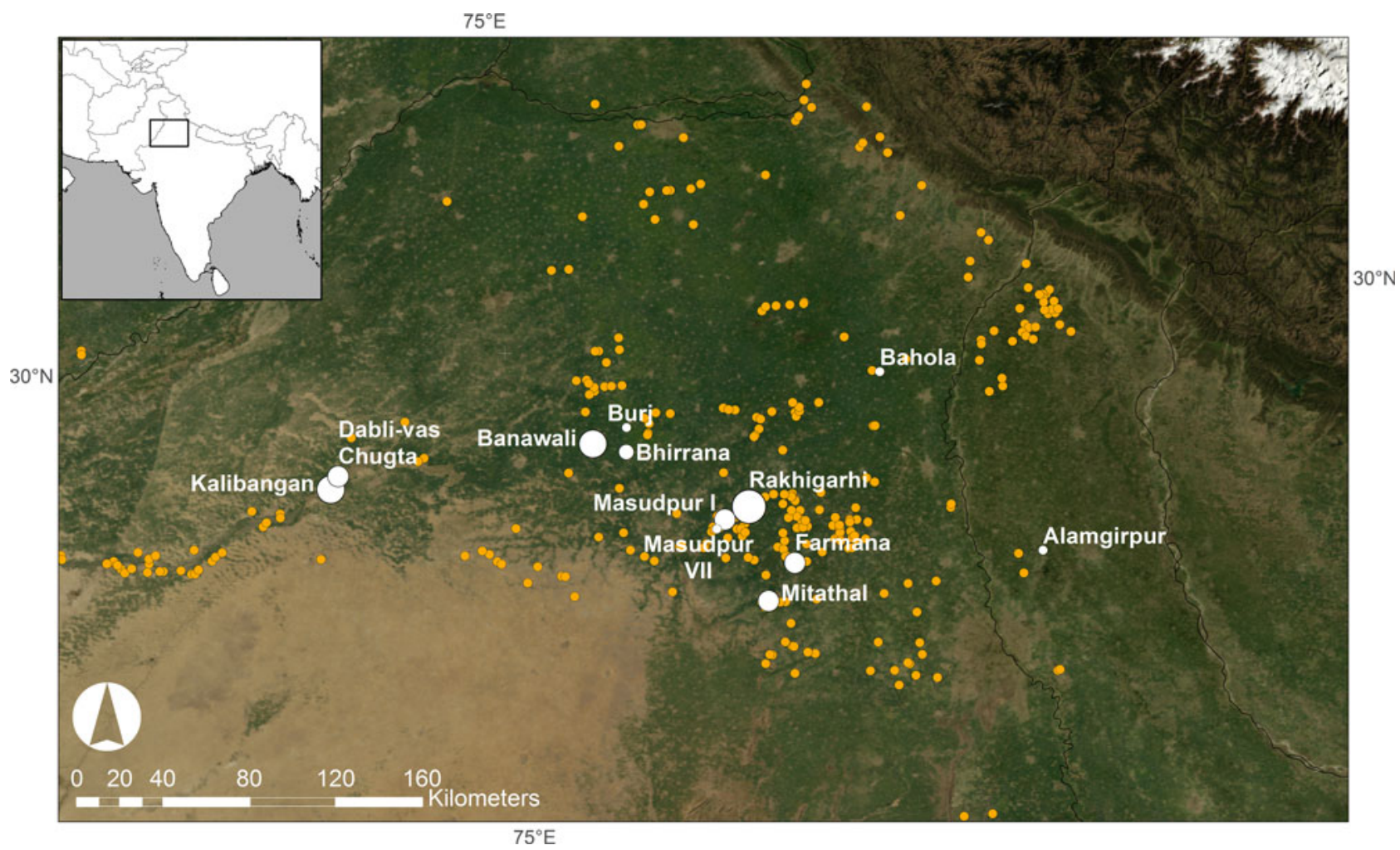

Figure 2. Map of the Sutlej-Yamuna interfluve of northwestern India, with sites studied by the Land, Water and Settlement project and other major sites in the region marked as white dots. The yellow dots show the other urban period Indus sites discovered through various surveys (map: C.A. Petrie). (For interpretation of the references to colour in this figure legend, the reader is referred to the web version of this article.)

2009, 2011; Kumar, 2009; Singh et al., 2010b, 2011, 2018; Parmar et al., 2013; Pawar et al., 2013; Sharan et al., 2013; see Green and Petrie, 2018). There has been a tendency to associate the distribution of Indus civilisation archaeological sites with the reconstructed courses of palaeochannels (e.g., Lal, 2002; Valdiya, 2002; Danino, 2010; Giosan et al., 2012; Singh et al., 2017). However, these relationships have not been explored in detail, they have typically been investigated at a very large scale, and the associations between the large urban centre of Rakhigarhi and the settlements in its hinterland, and the local landscape contexts and the palaeochannels that have been identified there, remain unclear.

The Land, Water and Settlement project was a collaboration between scholars from the University of Cambridge and Banaras Hindu University (2008-2014) that investigated the nature of long-term human and environment relationships on the plains of northwest India (Petrie et al., 2017). The project focused on the period from before the appearance of the cities of the Indus civilisation (Early Harappan: ca. 3000$2500 \mathrm{BC}$ ), through the period of their floruit and decline (Mature Harappan: ca. 2500-1900 BC), and the subsequent periods where rural populations made use of progressively changing assemblages of material culture (Late Harappan: ca. 1900-1600/1500 BC; Painted Grey Ware [PGW]: ca. 1500-700 BC). In addition, it also considered the Early Historic period, during which urban centres reappeared (Northern Black Polished Ware: ca. 700-200 BC; Early Historic ca. $500 \mathrm{BC}-\mathrm{AD}$ 500) and the Medieval period, when they continued to flourish (ca. AD 500-1500). Much of the research carried out by the Land, Water and Settlement project focused on the investigation of relatively small rural settlements, which appear to have housed the majority of the settled population during all three Indus periods (Madella and Fuller, 2006, fig. 9; Parikh and Petrie, 2019). The field and laboratory work included archaeological surveys and excavations, with the latter leading to integrated archaeobotanical, archaeozoological, stable isotope, and ceramic analysis. Within the overarching research programme, geoarchaeological analysis was conducted at a number of the Indus sites and their surrounding areas in Haryana and western Uttar Pradesh (Fig. 2).

In contrast to the diversity of the geoarchaeological research undertaken at Indus civilisation city sites (MohenjoDaro and Harappa), there has only been limited research on the geoarchaeology of rural or hinterland sites in Pakistan (e.g., Lahoma Lal Tibba, Chak Purbane Syal; Schuldenrein, 2002; Schuldenrein et al., 2004, 2007) and northwest India (e.g., Courty, 1985, 1990, 1995; Courty et al., 1987, 1989). This article presents the results and interpretations derived from sets of geoarchaeological samples recovered by the Land, Water and Settlement project from soil/sediment sequences in the immediate environs of the Indus sites of Alamgirpur (Mature Harappan, Late Harappan, PGW, and Medieval), Masudpur VII (Early Harappan, Mature Harappan, and Late Harappan), Masudpur I (Mature Harappan 
and Late Harappan), and Burj (Early Harappan, PGW, and Early Historic). This geoarchaeological investigation set out to gain insight into the location of settlements in the distinctive alluvial environment of northwest India, thereby helping us to understand why the people that established these settlements selected particular locations. In this regard, it was important to establish how the ancient land surfaces developed geomorphologically and pedologically and to ascertain whether there were any common attributes in terms of natural settings. It was particularly important to understand the nature of "local"-scale adaptations that Indus populations made to live in these landscapes in the third and second millennium BC.

\section{MATERIAL AND METHODS}

Soil profiles from the hinterland landscapes of each of the sites were recorded and sampled for micromorphological studies (Courty et al., 1989) and a suite of basic physical analyses (French, 2015: appendix 1) (Supplementary Section 1, Supplementary Table 1). The interpretations of the soil thin sections and associated small bulk samples from individual site areas are presented subsequently, along with the results of optically stimulated luminescence (OSL) dating of samples collected from deposits immediately below the oldest occupation levels at each of these sites. Details of all of the methods used and the descriptions of the soil thin sections and associated small bulk samples are in the Supplementary Materials (see Supplementary Section 1, Supplementary Table 2).

\section{Geoarchaeology}

Geoarchaeological approaches are well established and provide very powerful tools for understanding landscape change and associated human adaptation (French, 2015), particularly because of their ability to investigate and interpret environmental and cultural signatures that are typically concealed within the landscape itself (French, 2003). Geoarchaeological field research is aimed primarily at gathering data with which to understand human-landscape relations (Goldberg and Macphail, 2006), and for the study presented here, attention was specifically focused on examining the nature of the land surfaces and the associated soil properties of the plains of northwest India in close proximity to archaeological settlements. The specific aim was to situate Indus archaeological sites in their local environmental contexts. In order to achieve this aim, soil surveys at and around settlement sites were carried out with the use of hand-augering and hand-cut sections to reveal alluvial/occupation/soil/subsoil sequences. At each profile location, the stratigraphy was recorded and sampled for micromorphological and other geoarchaeological analyses (see Supplementary Section 1).

In total, nine "mammoth" soil blocks from a total of $15 \mathrm{key}$ soil profiles that were recorded (Supplementary Table 1) were prepared for thin section analysis at the McBurney Laboratory (Department of Archaeology, University of Cambridge) (after Murphy, 1986; Courty et al., 1989; Supplementary
Table 2). In addition, a suite of basic physical parameters ( $\mathrm{pH}$, loss-on-ignition for total organic and carbon contents, magnetic susceptibility, and particle size analysis) was carried out at the Department of Geography (University of Cambridge), on a series of small bulk samples taken in conjunction with the micromorphological block samples (Supplementary Table 3; Avery and Bascomb, 1974; Clark, 1996, pp. 99-117; French, 2015).

\section{Radiocarbon dating}

During the excavations of Alamgirpur, Masudpur I, Masudpur VII and Burj, bulk soil samples were collected for flotation, and the recovered material was used for archaeobotanical analysis and dating. Radiocarbon dates from Alamgirpur (Singh et al., 2013) and Masudpur I and Masudpur VII (Petrie et al., 2016) were analysed at the Oxford Radiocarbon Accelerator Unit (ORAU, RLAHA, Oxford), have already been published, and will be referred to where relevant in the subsequent text. The radiocarbon dates from Burj were also analysed at the ORAU and have not previously been published, but the relevant determination is discussed subsequently.

\section{Luminescence dating}

Samples for OSL dating were collected by hammering opaque tubes into the sediment stratigraphy, which were opened and prepared under subdued orange light conditions in the Oxford Luminescence Dating Laboratory (School of Geography and the Environment, Oxford; see Supplementary Section 1). A standard sediment preparation procedure was applied to isolate a purified quartz fraction suitable for dating. This involved the removal of carbonate and organic material using hydrochloric acid and hydrogen peroxide, followed by sieving and mineral separation using sodium polytungstate. Hydrofluoric acid was used to remove the alpha-irradiated outer layer of quartz grains, and samples were resieved prior to measurement. The OSL dates from each site are discussed in the subsequent individual sections. Single-grain OSL measurements were made using a Ris $\varnothing$ TL/OSL luminescence reader fitted with a $10 \mathrm{~mW}, 532 \mathrm{~nm}$ focused laser for stimulation and a ${ }^{90} \mathrm{Sr} /{ }^{90} \mathrm{Y}$ beta source (dose rate of $\sim 4$ $\mathrm{Gy} / \mathrm{min}$ ) for laboratory irradiation. Ultraviolet luminescence signals were detected through a bialkali photomultiplier tube fitted with $7.5 \mathrm{~mm}$ of U340 filters. Equivalent dose $\left(D_{e}\right)$ values were calculated from single grains of quartz (grain size range $150-180 \mu \mathrm{m}$ ) using the single aliquot regenerative dose (SAR) protocol (Murray and Wintle, 2000 ), with a preheat of $220^{\circ} \mathrm{C}$ for $10 \mathrm{~s}$ and cut-heat of $160^{\circ} \mathrm{C}$ both for $10 \mathrm{~s}$, selected following combined preheat and dose recovery tests. Dose recovery tests were used to assess the suitability of the SAR protocol for $D_{e}$ determination. Luminescence signals were measured at $125^{\circ} \mathrm{C}$ for $1 \mathrm{~s}$ at $90 \%$ laser power and $D_{e}$ values were calculated from the signal measured during the first $0.05 \mathrm{~s}$ of stimulation, with the mean background over the last $0.2 \mathrm{~s}$ subtracted. Luminescence signals were screened using a standard suite of rejection 
criteria, and only grains that satisfied the following criteria were accepted for age calculation: (1) recycling ratio within $10 \%$ of unity, (2) OSL IR depletion ratio (Duller 2003) within $10 \%$ of unity, (3) recuperation of less than $5 \%$, and (4) test dose signal at least $3 \sigma$ greater than background levels (Jacobs et al., 2003). Dominance of the fast component was assessed by applying the fast ratio (Durcan and Duller, 2011) to multi-grain quartz OSL signals. For the majority of samples, between 1500 and 3800 individual quartz grains were measured, with between $0.8 \%$ and $4.1 \%$ of grains providing luminescence signals discernible from machine background levels and that satisfied all rejection criteria. Dose distributions are moderately overdispersed (38\%-47\%; Table 4) for this suite of samples and are approximately symmetrical around a central value (Supplementary Fig. 1). This pattern suggests that overdispersion in the distributions is not caused by incomplete bleaching, which can be identified from skewed distributions. Instead, post-depositional factors, such as mild microdosimetric variability, as well as intrinsic intra-sample variability of quartz luminescence characteristics, are hypothesized to contribute to these spread in data. On this basis, the central age model (Galbraith et al., 1999) has been used for sample $D_{e}$ calculation, following the approach of Durcan et al. (2019).

Radionuclide concentrations were used for dose rate calculations, which were made using the dose rate calculator DRAC (v. 1.2; Durcan et al., 2015). Radioactivity was converted to dose rates using the attenuation factors of Guerin et al. (2011), and infinite-matrix dose rates were adjusted for attenuation by grain size, chemical etching, and moisture content $(5 \pm 2 \%) . D_{e}$ values and dose rates are summarised in Supplementary Table 4, along with the calculated OSL ages. Further details of the methods and the results are presented in Supplementary Table 4.

It is recognized that it is not feasible to directly compare the OSL and radiocarbon determinations (Jones, 1999). Nonetheless, the samples for the former were collected immediately below the earliest anthropogenic deposits, and those for the latter were collected from the earliest anthropogenic deposits containing datable material from each site. The OSL dates should thus closely correspond to the latest preoccupation deposition, and the radiocarbon dates should correspond to the earliest occupation deposits.

\section{ALAMGIRPUR}

\section{Site description}

The site of Alamgirpur (Meerut district, Uttar Pradesh; Fig. 2; Supplementary Section 2.1, Supplementary Fig. 2) is the easternmost excavated Indus site, and it was established in the urban phase of the Indus civilisation and occupied during the Mature and Late Harappan, PGW, and Medieval periods (Ghosh, 1958; Singh et al., 2013). The settlement is situated in a landscape composed of Quaternary alluvium to the east of the Yamuna River in the Hindon basin, which is part of the Ganges River basin (Singh, 1996). Today, the humid subtropical climate of this region has monsoonal characteristics, and it receives an average annual rainfall of about $800 \mathrm{~mm}$ (Weatherbase; http://www.weatherbase.com/weather/weather. php3?s=596039cityname=Meerut- India [accessed March 20, 2017]). The modern village of Alamgirpur lies adjacent to the left bank of the Hindon River floodplain, and the archaeological mound is located $\sim 2 \mathrm{~km}$ east of the current perennial river course (Supplementary Fig. 2).

The earliest deposits exposed in the YD2 and SC trenches at Alamgirpur have both been radiocarbon dated to ca. 4.34.0 cal ka BP (Singh et al., 2013, pp. 50-51, tables 10 and 11). These dates from different locations on the mound are statistically identical and internally consistent, suggesting that the mound was first occupied in the late centuries of the third millennium $\mathrm{BC}$, during the Indus urban period. An OSL date (CAM-9) was obtained from the "natural" sandy silt deposit immediately beneath the archaeological deposit in the SC trench from which the radiocarbon date was obtained. The date of $4.47 \pm 0.40$ ka predates the radiocarbon dates and suggests that the basal deposits on which the site was established were laid down in the period immediately before it was occupied.

\section{Sampling}

During a survey conducted in December 2010, a series of five profiles were observed in and around the mound, and soil block sampling was carried out (see Supplementary Section 2.1, Supplementary Figs. 2 and 3, and Supplementary Tables 1 and 2). The positions of the profiles were chosen to characterise the geomorphological setting and development of the archaeological site. Samples for micromorphological analysis were collected from profiles 1 and 3 (434-454 and 143$153 \mathrm{~cm}$ below the modern ground surface, respectively), as these locations were the most likely to reveal information on the environmental conditions prior to the occupation on this mound.

\section{Analytical results}

Schematic soil columns that reconstruct the stratigraphic profiles are shown in Figure 3. Sample 1/1 $(434-454 \mathrm{~cm})$ is mainly an apedal sandy soil, becoming a moderately welldeveloped subangular blocky silty clay loam with depth (Fig. 4; Supplementary Table 2). The few fragments of clay included in this soil are likely to be the products of recycling of the much older and preexisting "B" horizon material, which further indicates disruption, local reworking, erosion, and local deposition by biological and geomorphological agents (cf. Brewer 1960; Kuhn et al., 2010). Nonetheless, the oriented pure and dusty (silty) clay coatings present in the groundmass and voids as pedofeatures and some blocky ped soil structural evidence suggest that this was a palaeosol with a reasonably well-developed clay-enriched (or Bt) horizon (cf. Fedoroff, 1968; Retallack, 1990; Kühn et al., 2010), indicative of at least some stabilisation and pedogenesis in the past. In particular, the common illuvial features of 


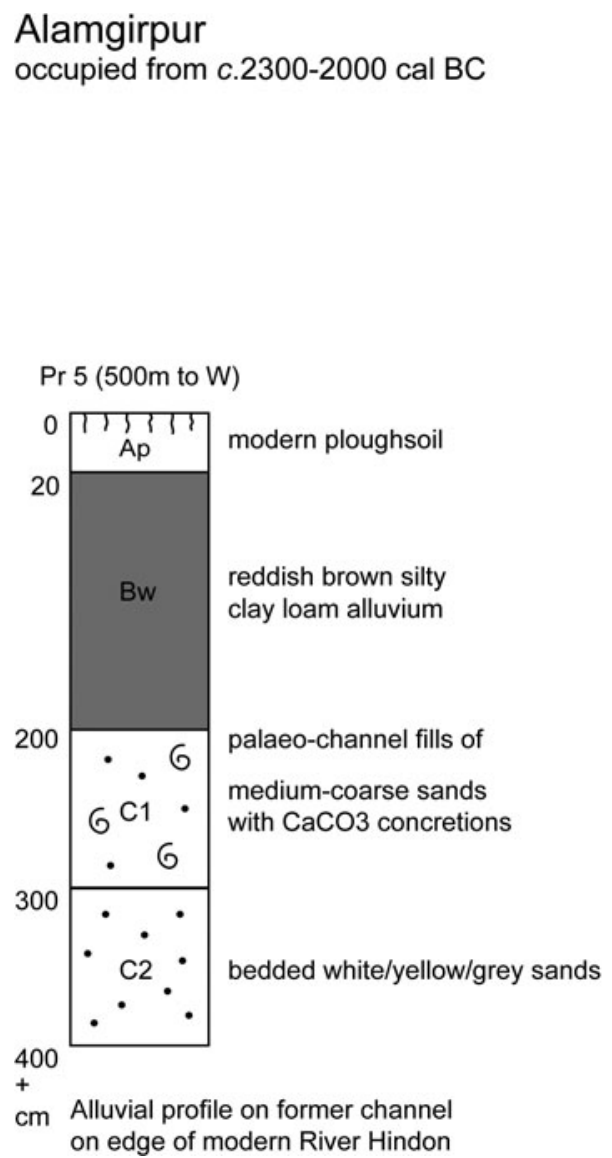

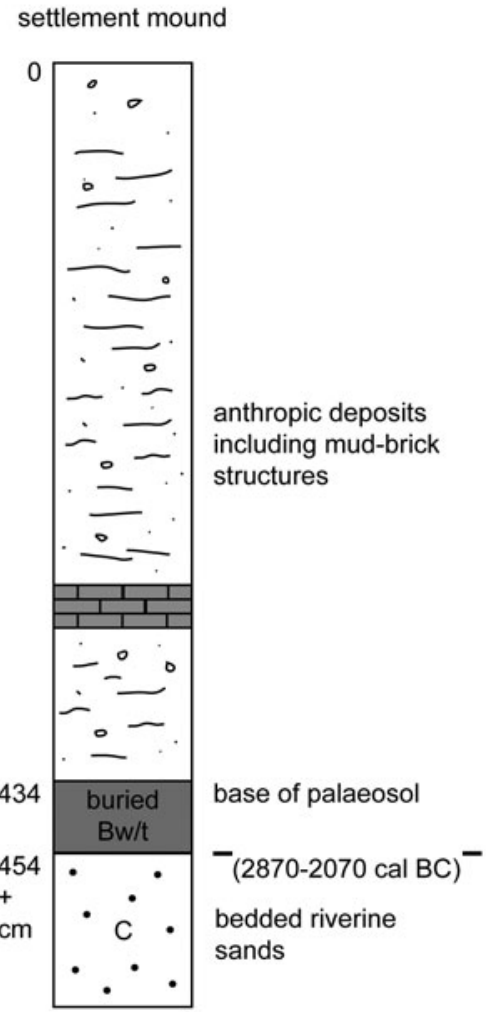

Buried dryland soil beneath Indus settlement mound

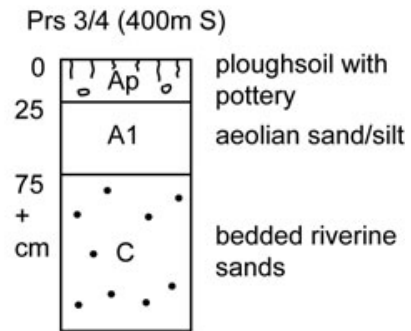

Wind-blown sand over palaeo-channel fills

Figure 3. Schematic depiction of soil profiles at Alamgirpur (image: C.A.I. French and C.A. Petrie).

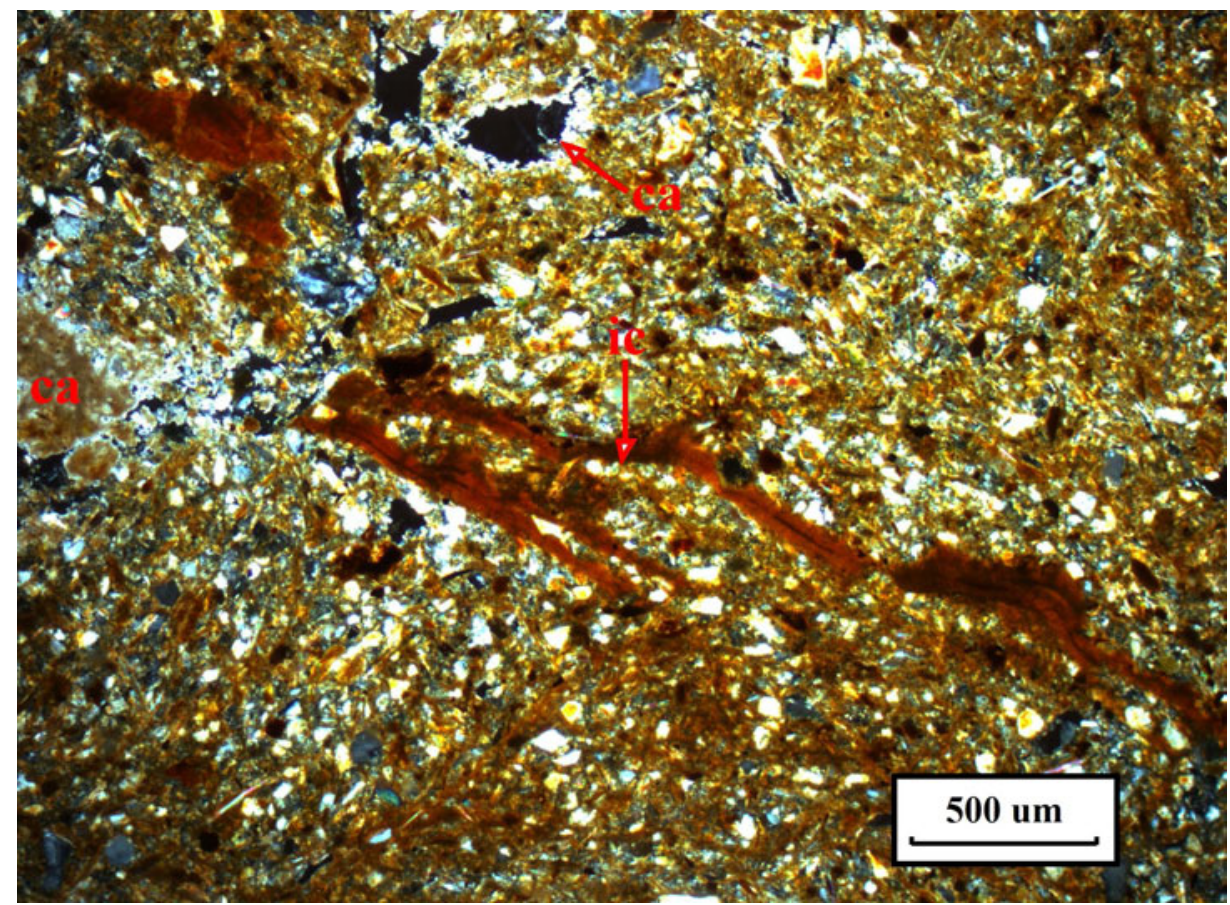

Figure 4. (colour online) Photomicrograph from Alamgirpur/off-site sample 1 showing a serrated intercalation of limpid and impure clay (ic). Notice the dominantly striated b-fabric, the calcite nodule (ca), and the calcite hypocoating (Cross Polarised Light, hereafter XPL) (photo: S. Neogi). 


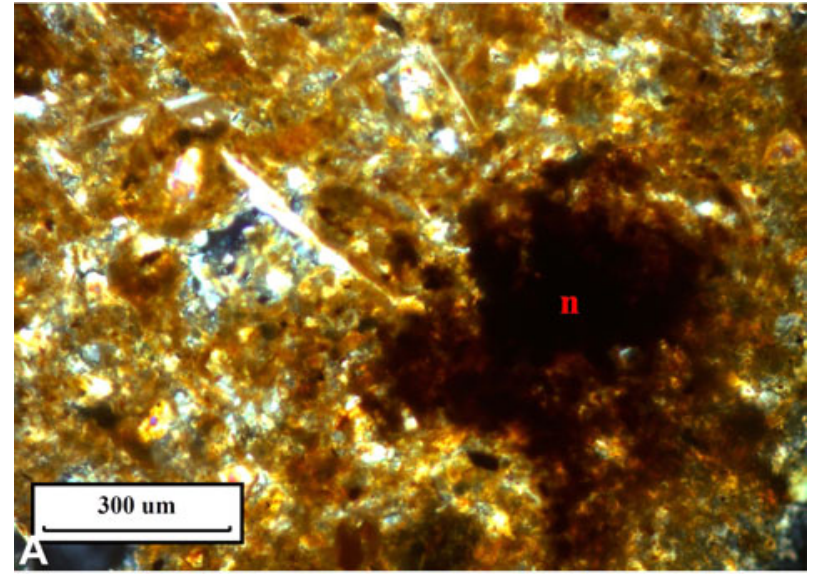

Figure 5. (colour online) Photomicrograph from Alamgirpur/offsite sample 1 showing a typic orthic nodule of iron oxide (n). Notice the diffused boundary (XPL) (photo: S. Neogi).

microlaminated pure and dusty clay striae and void coating features suggest that this soil was originally formed in a wellvegetated and stable environment (cf. Fedoroff, 1968; Retallack, 1990; Kühn et al., 2010), but the oxidation/gleying features suggest that this soil was seasonally wet (cf. Lindbo et al., 2010). The high organic content also suggests that this soil once supported a better surface vegetation (cf. Stolt and Lindbo, 2010), although the organic remains have been largely replaced by amorphous iron (Fig. 5), as a result of oxidization caused by the seasonal rise and fall of the groundwater table (cf. Lindbo et al., 2010). These soil properties indicate that there was some initial soil development during the earlier Holocene, which then became dominated by much wetter soil conditions. In contrast, sample 3 (143$153 \mathrm{~cm}$ ) showed a very fine sand interfacing with horizontally bedded white micaceous river sand. It is suggested that the "soil horizon" observed in this profile is a former weathered surface of a levee formed from riverine deposition of the nearby Hindon River. The ancient mound and the modern villages of Alamgirpur and Nandapura are all situated along a levee at the eastern edge of the Hindon floodplain (see Supplementary Fig. 2).

\section{Interpretation}

From the general landscape survey and detailed micromorphological analyses, it can be suggested that the current floodplain/valley edges of the Hindon River are defined by irregular but linear arrangements of sand dunes (ca. 6-8 m high), the origin of which are levees. The spatial configuration of these geomorphological features indicates that levee formations probably began to develop during the Late Quaternary, followed by cycles of soil formation and flooding. The latter process is evidenced in sample $1 / 1$, which shows some disruption through the inclusion of fragments of a preexisting palaeosol in the form of well-developed clay fragments (Supplementary Table 2). Sample 3 represents a fluvisolic palaeosol formed from the deposition of alluvial sediments by the river. Indus period pottery fragments were found within the soil matrix, suggesting that soils were being worked in this period.

These geoarchaeological analyses highlight the formation sequence and postdepositional transformations of the early Holocene palaeosol and the alluvial sequence in the Hindon basin, adjacent to Alamgirpur. The indications of soil formation seen in the micromorphological analysis indicate that this process occurred well before the Indus populations targeted this location for permanent settlement (Fig. 3). Thus, this particular location may well have been chosen for establishing a settlement because it remained above the flooded zone and/or it had soils suitable for agricultural use.

\section{MASUDPUR I AND MASUDPUR VII}

\section{Site descriptions}

The mound sites of Masudpur I and Masudpur VII (Fig. 2; Supplementary Section 2.2 and Supplementary Fig. 4) are situated in a part of the Sutlej-Yamuna interfluve that today has a semiarid climate and is characterised by scanty and irregular rainfall, hot summers, dry cold winters, prevalent aridity, and desert and saline soils (Kottek et al., 2006; Petrie and Bates, 2017; Petrie et al., 2017). Masudpur I was a large village- or town-sized settlement (6-8 ha) occupied in the Mature and Late Harappan periods, and Masudpur VII was a small village-sized settlement (1 ha) occupied in the Early, Mature, and Late Harappan periods (Petrie et al., 2009, 2016; Parikh and Petrie, 2016, 2019).

Today, the area around these settlement sites consists of a flat to undulating plain partly covered with intermittent sand dunes (Petrie et al., 2009). Sediments have been characterised as mainly fine alluvium derived from the Himalayas with an admixture of wind-blown sand from the Thar Desert of Rajasthan, to the southwest (Courty, 1985; Bhatia and Kumar, 1987). It has long been argued that the alluvium was primarily deposited during the Quaternary by large rivers that have since dried up (Ahuja et al., 1980), but rainfall and hydrologic activity during the earlier Holocene have also had a major impact on the distribution of sediments on the floodplain.

The earliest deposits exposed in the XA1 and XM2 trenches at Masudpur I have been radiocarbon dated to ca. 4.4-4.1 cal ka BP (Petrie et al., 2016, table S7), suggesting that the mound was first occupied during the Indus urban period. OSL dates obtained from the "natural" sandy silt deposit immediately beneath the archaeological deposits in each of these trenches were obtained, and their ranges are $4.89 \pm 0.37 \mathrm{ka}$ for sample CAM-1 (Trench XA1/XM2) and $4.01 \pm 0.31 \mathrm{ka}$ for sample CAM-3 (Trench XA1/XM2), with the range of the latter overlapping with the earliest radiocarbon dates. The closeness of these dates suggest that the final phase of basal deposits on which the site was established were laid down shortly before that process took place.

The earliest radiocarbon date from the deposits exposed in the YA2 and YB1 trenches at Masudpur VII is ca. 4.9-4.6 cal ka BP (Petrie et al., 2016, table S6), suggesting that the 


\author{
Masudpur I \\ occupied from c.2400-2140 cal BC
}

settlement mound

area
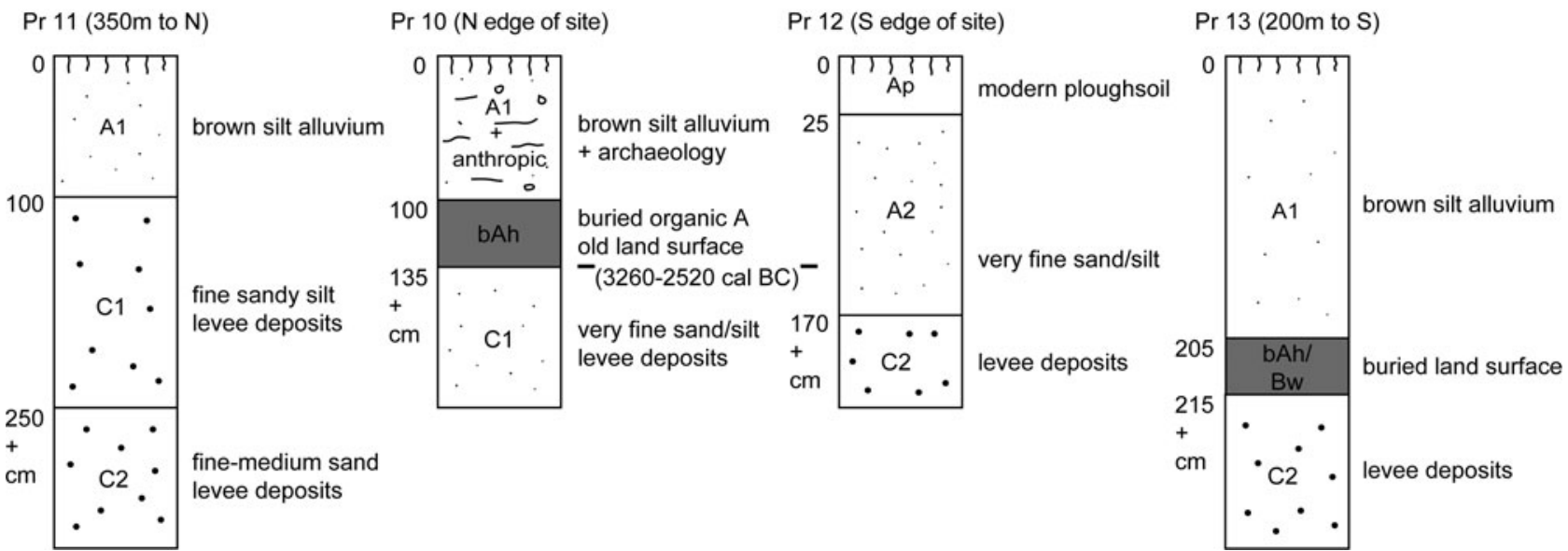

Figure 6. Schematic depiction of profiles at Masudpur I (image: C.A.I. French and C.A. Petrie).

mound was first occupied before the Indus urban period. OSL dates obtained from the "natural" sandy silt deposit immediately beneath the archaeological deposits in each of these trenches date were obtained, and their ranges are 7.32 \pm $0.59 \mathrm{ka}$ for sample CAM-5 (Trench YA2) and $6.47 \pm 0.52$ ka for sample CAM-3 (Trench YB1). The luminescence and radiocarbon dates taken together suggest that the basal deposits on which this site was established were laid down several millennia before the settlement was founded, assuming that no later sediments had been removed by natural or anthropogenic processes.

\section{Sampling}

Geoarchaeological survey of the environs of these sites was undertaken in March 2010, with one profile being recorded near Masudpur VII (profile 15) and a series of four profiles (profiles 10,11, 12, and 13) being investigated to the north, south, and southeast of the surviving mound of Masudpur I (Supplementary Fig. 4, Supplementary Tables 1 and 3). These locations were chosen with the aim of characterising the geomorphological development of the respective archaeological sites. Masudpur VII profile 15 was observed within the exposed archaeological section of trench YB1 (Supplementary Table 1). The profile shows that the site was established on a sand dune at the terminal end of a north-south oriented chain of dunes, and there are no modern watercourses flowing in the immediate vicinity of the sampling location.

\section{Analytical results}

Schematic soil columns that reconstruct the stratigraphic profiles are shown in Figure 6. Profile 10 was exposed $100 \mathrm{~m}$ to the north of excavation trench XA1 at Masudpur I (see Petrie et al., 2009, 2016). Underneath $\sim 1 \mathrm{~m}$ depth of Indus period archaeological deposits at profile 10 , there was a $35-\mathrm{cm}$-thick older land surface comprising organic, dark greyish brown very fine sandy silt over pale brown very fine sandy silt (Supplementary Fig. 5). This stratum developed on a substrate of pale yellowish brown and calcitic very fine sandy silt with frequent calcitic nodules. Profile 11 was exposed $350 \mathrm{~m}$ farther to the north of profile 10 and was characterised by $1 \mathrm{~m}$ of brown silt over $1.5 \mathrm{~m}$ of yellowish/greyish brown fine sandy silt to fine-medium sand with depth. Here, no old surface or soil development was evident. Profile 12 was a well cutting, $50 \mathrm{~m}$ to the south of the farmstead adjacent to the settlement mound, and revealed a depth of $>1.7 \mathrm{~m}$ of homogeneous brown very fine sandy silt with frequent pottery sherds. Profile 13, a dry well $200 \mathrm{~m}$ to the southeast of the farmstead recorded $2.15 \mathrm{~m}$ of similar homogeneous brown very fine sandy silt above a yellowish brown fine sandy silt. Samples for micromorphological analysis were collected from profiles 10 and 13 (see Supplementary Section 2.2).

There is relatively little textural difference between profiles 10 and 13, with sand predominating along with a considerable silt content, but relatively low values of clay present (see Supplementary Section 2.2, Supplementary Table 3). The physical characteristics of the Masudpur profiles exhibited strongly alkaline conditions ( $\mathrm{pH}$ of 8.61 to 9.36), as well as relatively low percentages of organic $(0.95 \%$ $1.26 \%)$ and calcium carbonate $(2.6 \%-7.2 \%)$ contents and low magnetic susceptibility values $\left(<20.3 \mathrm{SI} / \mathrm{kg} \times 10^{-8}\right.$ ) (Supplementary Table 3). Nonetheless, this soil exhibits illuvial clay and dusty clay that formed coatings and striae in the subsoil horizon (Fig. 7; see Supplementary Section 2.2), much like that observed in profile 1 at Alamgirpur, thus suggesting that this soil developed under stable, well-vegetated, and 


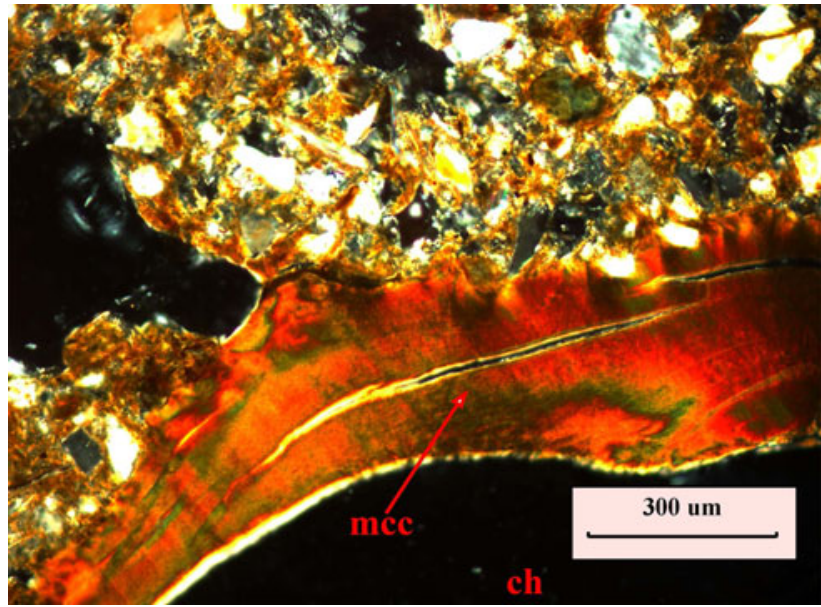

Figure 7. (colour online) Photomicrograph from Masudpur I sample 13 showing continuous coating of well-orientated, microlaminated reddish-brown clay $(\mathrm{mcc})$ around a channel (ch). Note the characteristic extinction band (XPL) (photo: S. Neogi).

well-drained conditions for a length of time prior to the combined effects of groundwater rise and fall and burial by Indus occupation deposits.

The surficial geology beneath Masudpur I appears to be composed of finely bedded sands that are suggestive of former channel fill deposits now surviving as low sinuous ridges (Fig. 6; also Supplementary Section 2.2). The lower-lying areas of the adjacent plain were probably more or less continually affected by the slow, seasonal deposition of alluvium from overbank flooding, presumably associated with monsoonal rains (cf. Gibling et al., 2005; French et al., 2017). Subsequent stability in this system appears to have led to the development of a well-developed soil with organic $\mathrm{Ah}$, eluvial $\mathrm{Eb}$, and illuvial clay-enriched Bt horizons present (see Supplementary Section 2.2). This type of former soil (or Luvisol) would have provided excellent cultivable land for people who appear to have settled on the well-drained higher ground of the former sand bars/ridges.

\section{Interpretation}

The surrounding, more low-lying areas are likely to have received alluvial silt deposition seasonally, which would have provided both moisture and nutrients to the soil. This process might have significantly improved the fertility of these levee margin soils, by adding humic, silt, and clay contents to the fine sandy soils, thereby helping to maintain soil structure and the productive capacity of farming in this landscape. However, real improvements in fertility and crop yields would have probably required sustained additions of organic waste, minimal tillage, and multicropping regimes (Weber et al., 2007; Berner et al., 2008), and there is palaeobotanical evidence for multicropping practices at these sites (Petrie and Bates, 2017). Nonetheless, the degree of development of the soil properties shows that the soil system was stable for a relatively long period, and this could have coincided with the Indus occupational phases.

In general, the textures of the soils around the Masudpur I mound are very sandy, and they are therefore very well drained (Fig. 6). However, the micromorphological analysis at Masudpur VII suggests that the soil in that area is comparatively less sandy with a slightly loamier texture. The downprofile illuvial movement of clay and silty clays are evident in almost every thin section, albeit in relatively small amounts, indicating both phases of relative stability and some soil formation, as well as the continuing seasonal influence of alluvium additions at both of these sites.

\section{BURJ}

\section{Site description}

The site of Burj (see Fig. 2; Supplementary Section 2.3, Supplementary Fig. 6) is situated on the Sutlej-Yamuna interfluve some distance to the north of Masudpur and sits adjacent to the Ghaggar palaeochannel on the opposite side to the wellknown Indus site of Kunal. Today, this region has a semiarid climate and appears to be drier than the area around Masudpur (Courty, 1990; Kottek et al., 2006; Petrie and Bates, 2017; Petrie et al., 2017).

The earliest deposits exposed at the site were in the ZG9 trench (Singh et al., 2010a), and the earliest radiocarbon determinations from there have been dated to ca. 4.8-4.5 cal ka BP (Context 216: OxA-26475, $4031 \pm 34$ BP), which suggests that the mound was first occupied during the Indus preurban period, though there was also evidence for occupation during the PGW period. One OSL date was obtained from the "natural" sandy silt deposit immediately beneath the archaeological deposits in a neighbouring trench, and its range was $5.48 \pm 0.42 \mathrm{ka}$ for sample CAM-11 (Trench ZA2). The OSL and radiocarbon dates taken together suggest that the basal deposits on which the site was established were laid down up to a millennium before the settlement was founded.

\section{Sampling}

Five profiles (profiles 1, 2, 3, 72, and 73) were recorded on and around the surviving mound at Burj, which is partially overlain by the modern village (Supplementary Section 2.3, Supplementary Fig. 6, Supplementary Tables 1-3). These profiles were selected in order to characterise the geomorphological context of soils associated with the archaeological site.

\section{Analytical results}

Schematic soil columns that reconstruct the stratigraphic profiles are shown in Figure 8. Profile 1 was located $\sim 30 \mathrm{~m}$ northeast of the present-day edge of the mound and revealed that $40-65 \mathrm{~cm}$ of modern ploughsoil, which had recently been removed by villager quarrying, overlying a $50-\mathrm{cm}$-thick 


\section{Burj}

occupied from c.2830-2470 cal BC
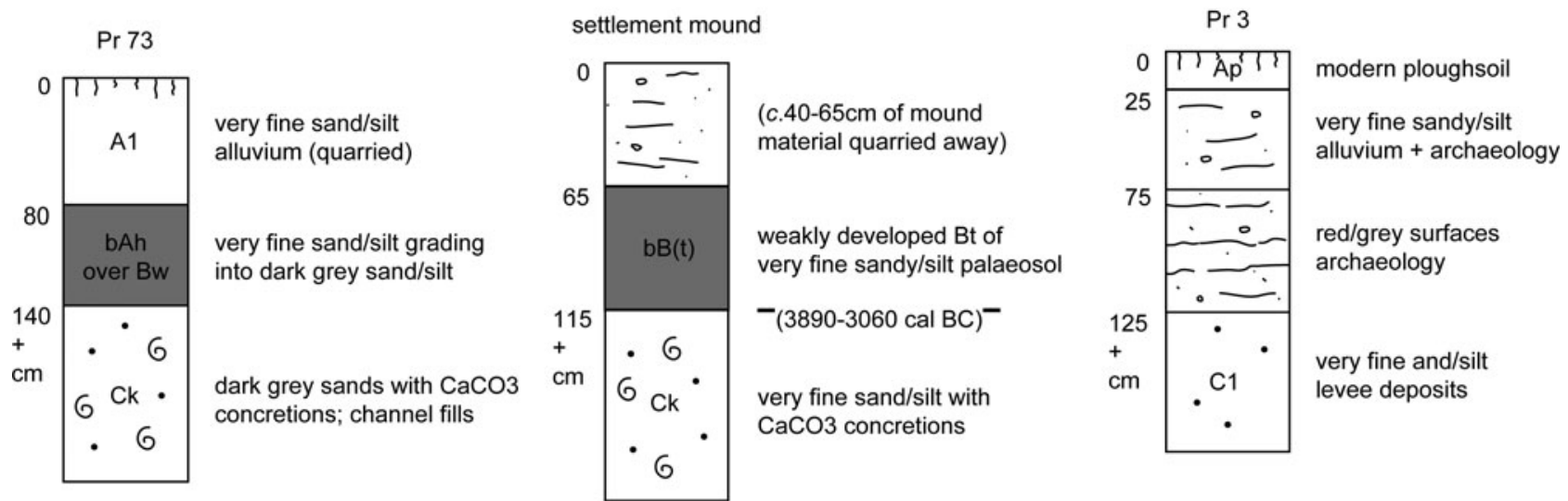

Figure 8. Schematic depiction of profiles at Burj (image: C.A.I. French and C.A. Petrie).

horizon of yellowish brown, very fine sandy silt, containing occasional bivalve shells, developed on a pale yellowish brown calcitic silt with irregular calcitic nodules (Supplementary Fig. 7). The bivalves have not been assessed in detail, but their presence is interesting given the settlement's proximity to the Ghaggar palaeochannel and suggests that ponding may have resulted from the flooding of parts of the surrounding landscape during periods of seasonal rain. This entire profile was cut by a substantial pit containing PGW period pottery. Profile 2 (Supplementary Fig. 8) was exposed on the northern edge of the settlement mound and had similar properties to that of profile 1, without the intrusive pit. Profile 3 was exposed $100 \mathrm{~m}$ to the east of the modern Sikh temple that is situated on the highest point on the mound. The upper $75 \mathrm{~cm}$ of this profile was composed of a homogeneous, pale brown silt with occasional pottery sherds, which developed on a $50 \mathrm{~cm}$-thick horizon of horizontally banded archaeological levels of alternating dark reddish brown and pale grey silt. This deposit had in turn accumulated on a pale yellowish brown calcitic silt similar to that already seen in profiles 1 and 2. Profile 72 was cut $120 \mathrm{~m}$ east of trench ZA2. Archaeological deposits were found to a depth of $120 \mathrm{~cm}$ and overlaid pale yellowish brown sandy silt with concentrations of calcium carbonate, which may indicate the presence of a channel fill deposit. Profile 73 was located $600 \mathrm{~m}$ southwest of the archaeological trench of ZA2, amidst a field that was reported as being $80 \mathrm{~cm}$ higher some $10 \mathrm{yr}$ earlier, after which time it had been levelled to reach the elevation of the surrounding fields. The profile showed $30 \mathrm{~cm}$ of modern topsoil over 30-60 cm of dark greyish sandy silt. Very few sherds of pottery were found from the dark greyish sandy silt, and it was situated on pale yellowish sandy silt with concentrations of $\mathrm{CaCO}_{3}$, again possibly indicative of the presence of channel fill deposits.

A representative set of three block samples from different depths in profile 1 were selected for micromorphological analysis (Fig. 9; Supplementary Section 2.3). The micromorphological analysis clearly exhibits the illuvial movement

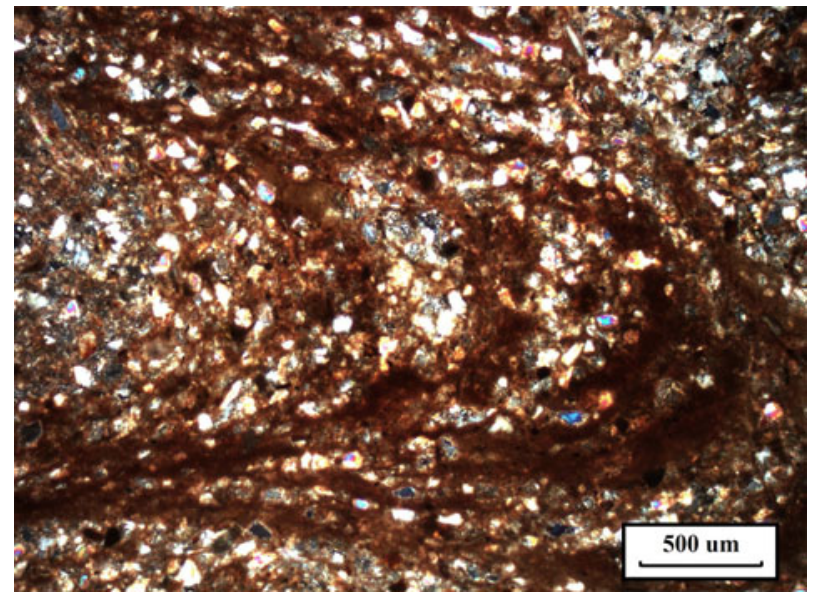

Figure 9. (colour online) Photomicrograph from Burj sample 1/1 showing a passage feature (XPL) (photo: S. Neogi).

down-profile and the formation of pure clay and silt coatings, which suggests that pedogenesis was taking place, more or less coincident with the Indus occupation. In particular, the illuviation of pure and dusty clays is only possible when the soil $\mathrm{pH}$ is circum-neutral to slightly acidic, and there are stable, moist, and well-vegetated conditions over a considerable length of time, allowing an argillic (or Bt) horizon to develop (Fedoroff, 1968, 1972; Bullock and Murphy, 1979; Kühn et al., 2010; IUSS Working Group WRB, 2014). In contrast, the dominant soil forming process in the region today is calcification and high alkaline $\mathrm{pH}$ levels, with concomitant seasonally very severe aridity and strong evaporation of soil water in the near surface soil system. These two different processes are unlikely to have developed at the same time (cf. Srivastava and Parkash, 2002). It therefore seems that the soil at Burj was in a unique state of development during the Indus period (Fig. 8), which was not analogous to today, just as has been observed at Alamgirpur and Masudpur. 


\section{Interpretation}

These relatively well-developed soils existing in river edge locations associated with several Indus sites implies a certain level of stability in the floodplain margins and a moister palaeoenvironmental regime. Additionally, the proximity of the river channels and fine overbank flooding from time to time would have continued to benefit agricultural exploitation.

\section{DISCUSSION}

This analysis of the buried soils and underlying geomorphological features related to Alamgirpur, Masudpur I, Masudpur VII, and Burj provides a number of important insights into landscape development and geomorphology on an extensive alluvial floodplain in northwest India and, particularly, the importance of this environment for Indus settlements and their hinterlands. These environments are distinct from those occupied by populations in ancient Egypt and Mesopotamia, most particularly because of the influence of both winter and summer rainfall systems and also the combination of an extensive floodplain watered by a combination of perennial and ephemeral river channels. This study highlights the fact that farmers occupying seasonally inundated alluvial plains subject to flooding are constantly faced with risks to which they must adapt. Analysis of the archaeobotanical evidence from these sites has shown that farmers made use of strategies that enabled them to exploit combinations of summer and winter crops that required differing quantities of water, suggesting an awareness of the nuances of living and farming in such landscapes (Petrie and Bates, 2017).

With the exception of two sites located close together (Masudpur I and VII), the ancient settlements considered in this article were situated considerable distances apart. In principle, the landscape information from each site should be treated as being relatively discrete, but importantly, they share a number of similarities. For instance, all four of these Indus settlement sites were situated on former sandy levees or riverbank deposits of Quaternary river systems, which also appear to have been active during the early Holocene. These features are evident in the geomorphic sampling locations (Fig. 10) and also in processed digital elevation models that highlight microrelief (Fig. 11). These locations were both slightly higher in elevation and also better drained than the surrounding lower-lying alluvial plain landscapes and were more likely to have remained above the floodwater levels and associated disruption during the wet season. These

\section{Burj occupied from c.2830-2470 cal BC}

\section{Masudpur I occupied from c.2400-2140 cal BC}

\section{Alamgirpur occupied from c.2300-2000 cal BC} settlement mound

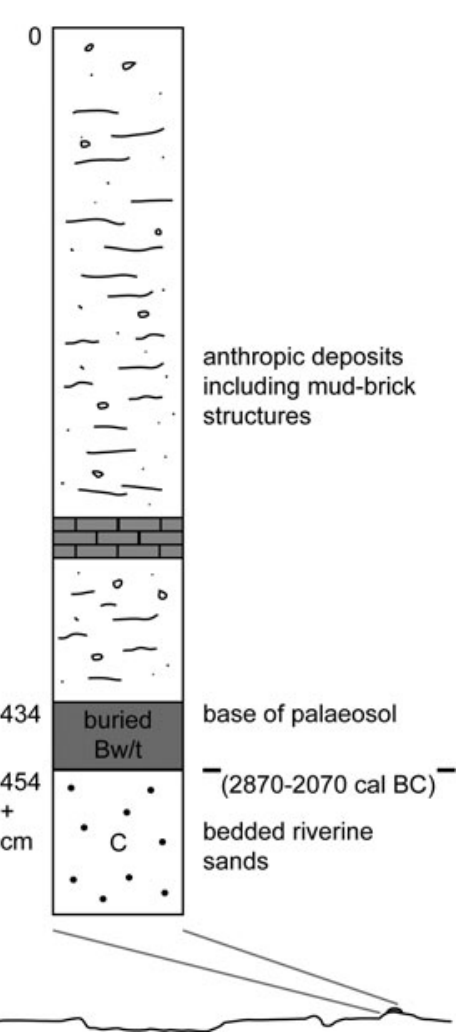

Figure 10. Schematic illustration comparing the relationship between the settlements at Burj, Masudpur I, and Alamgirpur and their underlying soil and levee deposits, above a diagrammatic representation of a section across the Sutlej-Yamuna interfluve, showing multiple channels, and settlements situated on elevated areas. 


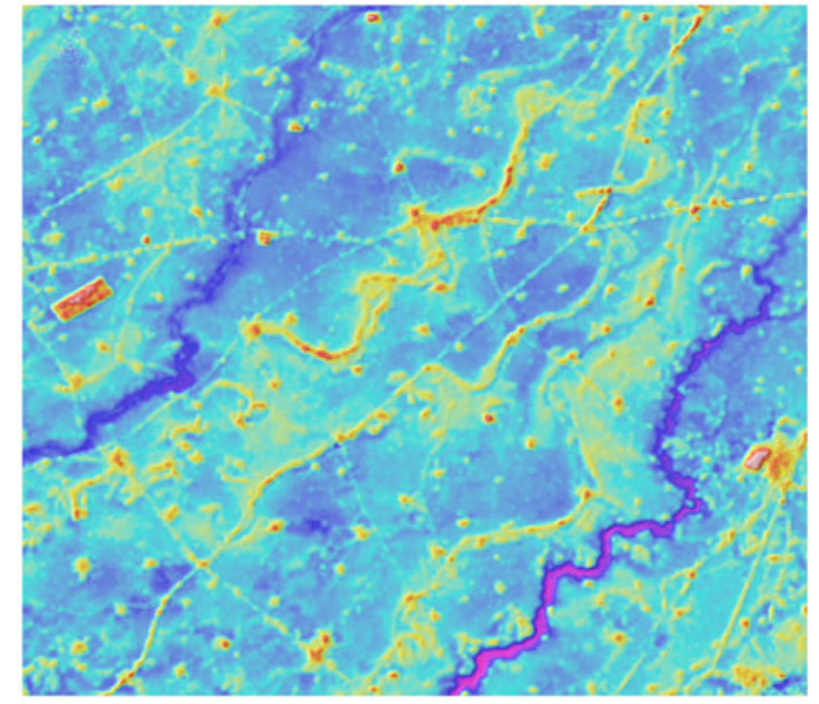

Figure 11. Detailed digital elevation model (DEM) of an area of the Sutlej-Yamuna interfluve that provides a particularly clear illustration of the plains geomorphology, highlighting the form and relative elevation of the levees (visible as yellow meanders), areas of lower terrain (in light blue), and the courses of a number of palaeochannels (in dark blue). This DEM image was produced by H. Orengo using $12 \mathrm{~m}$ TanDEM-X imagery (after Orengo and Petrie, 2018, fig. 2). (For interpretation of the references to colour in this figure legend, the reader is referred to the web version of this article.)

levees appear to have been widely targeted for both settlement and agricultural exploitation, and it is notable that this has also been observed at Harappa, which is situated in a different part of the Indus River basin (Belcher and Belcher, 2000; Schuldenrein et al., 2004, 2007). Importantly, these slightly elevated areas had relatively well-developed soils, unlike those in the area today, which would have been a significant beneficial factor for these settlements. In contrast, the adjacent lower-lying parts of the landscape were characterised by much finer textured soils derived from silts and clays, indicating the continuing seasonal input of fine overbank alluvial material into an aggrading floodplain system. These patterns are distinct from those seen in the lower parts of the Indus River basin, where the major river channels of Punjab have consolidated into larger channels, which produced sizable meanders and show evidence of pronounced migration over the last 4000 yr (Flam, 1993, 1999; Schuldenrein et al., 2007).

The micromorphological analysis presented here demonstrates that the former land surfaces on levees and their margins in different parts of northwest India exhibited reasonably well-drained and structured soils that had undergone some pedogenesis. Importantly, these soils all contain a relatively minor but significant fine illuvial silt and clay content in the voids and groundmass, unlike the sandy subsoils beneath. The consequent silty clay "argillans" that occur in semidesert soils in this region have been interpreted as being a result of in situ weathering (Kooistra, 1982) or being derived from the breakdown of fine particles related to surface crusting and seasonal floods (Courty and Fedoroff, 1985). As vegetation cover is often poor/degraded in semiarid areas, surface crusts may modify the easy downward translocation of fines into deeper horizons. Sandy soils with a single grain structure also act as a very favourable porous medium for water infiltration and percolation, especially under semiarid conditions. Suspended clay and silt are deposited in water films and preferentially deposited around sand grains by capillary action. Also, the strong adherence of clay particles to the sand grains explains the persistence of clay when these soils have been partly reworked by the wind (Wieder and Yaalon, 1978).

These soils also exhibit more ubiquitous gleyic properties, which are normally a consequence of seasonal wetting and drying and proximity to the groundwater table (cf. Lindbo et al., 2010). It is difficult to be sure whether this relates to modern and/or past monsoonal flooding and alluviation, but given today's extensive network of pump irrigation and control of groundwater levels, it is unlikely that it can be ascribed solely to past causes.

Importantly, the buried palaeosols with more welldeveloped silt- and clay-enriched B horizons that have been observed do not show the accumulation of calcium carbonate $\left(\mathrm{CaCO}_{3}\right)$, which is ubiquitous in most modern soils of this region. This signals that transpiration and evaporation did not outweigh precipitation (Durand et al., 2010). The absence of these properties in the palaeosols associated with the welldeveloped Bt horizons at Alamgirpur, Masudpur, and Burj suggests that the climatic and vegetational conditions at these sites were somewhat different in the past than today. These soils must therefore have been better vegetated and more moist and, consequently, under a different precipitation and groundwater regime, and thus potentially more fertile. This observation is notable as significant shifts to drier conditions in this region have been identified at different points during the Holocene (Dixit et al., 2014a, 2014b, 2018). Climate models for the region around Harappa (Wright et al., 2008) and palaeoclimatic proxy records from various locations in northwest India (Dixit et al., 2014a, 2018) suggest that the mid-Holocene was characterized by relatively stronger winter and summer rainfall, and a reassessment of a sediment core off the Pakistani coast has indicated that both rainfall systems were weaker from $4.2 \mathrm{ka}$ (Giesche et al., 2019; also Dixit et al., 2014a). The weakening of these precipitation regimes occurred during the mid-late phases of the Indus urban period, during which Masudpur I, Masudpur VII and Alamgirpur were all occupied.

The slow-moving floodwaters associated with seasonal inundation and overbank flooding through monsoonal run-off appear to have contained clay, silt, and fine organic matter, which would have replenished the soils annually. In turn, these fine alluvial additions would have gradually altered soil textures to be finer and more moisture retentive, counteracting the detrimental effects of the free-draining sandy parent material (cf. Moody, 2006), and thus affecting fertility positively. Furthermore, these soils could have been easily worked (cf. Greenman et al., 1967), even without the need for ploughing, which would facilitate simple forms of agriculture (cf. Hillel, 2004). Seasonal flooding would have 
also mitigated against water stress, especially for moisturehungry cereal crops. Consequently, these soils that were associated with Indus urban period settlements had a degree of stability and resilience supported by annual replenishment. Thus, both the levees and their floodplain margins could have been relied on to support annually successful arable crops. It is also possible that the association of these alluviated "good" soils with large artefact scatters around these settlements may imply a form of fertilisation with domestic refuse to additionally enhance the properties of these levee soils (cf. Wilkinson, 2003, pp. 117-118).

The associated river systems and their lower-lying floodplains adjacent to the settlement sites were regularly affected by the seasonal aggradation of overbank flood deposits. These were mainly composed of fine sand and silt as soil runoff associated with monsoonal rains and riverine flooding and gradually encroached onto the soils on the margins of the higher areas of the levees. This led to some new soil processes occurring such as gleying and the secondary formation of calcium carbonate and amorphous oxides, as well as soil thickening and textural alterations with sand/silt alluvial sediments and/or the reworking and secondary deposition of channel bed derived sands. These potentially extensive "skirtland" alluviated areas around every site would have initially also provided a naturally and seasonally replenishing soil and groundwater system available for agricultural use with both nutrient and fine soil additions and a seasonally high groundwater table. Over time, these areas would have become seasonally very dry, calcitic Fluvisols and would therefore have been "too risky" for maintaining a viable cropping regime until more recent times without drainage and/or nutrient additions.

Other studies of the pre-Indus civilisation soil complexes are relatively few and far between, with the investigation of the Upper Beas palaeochannel and associated floodplain margin soils associated with the sites of Harappa, Lahoma Lal Tibba, and Chak Purbane Syal offering the most comparable analytical detail (Schuldenrein et al., 2004, 2007). Essentially three phases of pre-Indus civilisation soil formation have been recognized that exhibit remarkable similarities to the picture that has emerged from our study of sites much farther to the east in the Ghaggar-Hakra valley zone of northern India. These Upper Beas soils are typically preserved on the margins of slightly higher areas of ground on channel/ floodplain margins. The earlier Holocene phase (ca. 10-7 ka) saw the development of weakly developed A-B horizon soils, which show some signs of clay illuviation and overlay either Bk and/or Ck horizons with carbonate nodules, often with thick, late Quaternary alluvial or wind-blown deposits beneath. In the second period between ca. 7 and $4 \mathrm{ka}$, these soils developed further into A-B-Bwt profiles with the argillic Bt horizon exhibiting particular development. Then, just before the settlement mounds were established by about 2400-2200 cal BC, there was a more mixed and increasingly unstable picture with the first signs of overbank alluviation and channel avulsion.

Thus, there again appears to be clear evidence of the stabilization of floodplain margin landscapes with optimal climatic conditions with a stable rainfall regime and moderate evapotranspiration, which enables good soil development during the early to mid-Holocene. This was followed by some destabilisation of the environment and the development of thinner soils with channel migration just before the urban phase of the Indus civilisation.

\section{CONCLUSIONS}

This geoarchaeological study has shown that at least some and perhaps many Indus populations living on the Sutlej-Yamuna interfluve had a preference for targeting low terraces and sandbar/ridges on the margins of the ancient floodplains for the establishment of their settlements. Although the immediate environs of only four sites have been investigated, their floodplain edge locations would have reduced the risk of settlements being inundated, which would certainly have affected the adjacent alluvial plains throughout the Holocene, and are documented up to the present. Significantly, the combination of relatively good soils on these areas of higher ground and the associated naturally and seasonally replenishing alluvial soil system adjacent combined to provide a most important resource that assured agricultural sustainability. Moreover, this earlier to mid-Holocene soil development can only have been associated with a better moisture regime with less risk of drought, and relative landscape stability, which is mirrored by geoarchaeological and soil analytical studies in the Upper Beas (Schuldenrein et al., 2004). This combination of factors is probably the essence of the establishment and sustainability of the agricultural system in this region during the Indus periods. This type of relationship between humans, their locale, and good soil development is an important aspect of Indus cultural adaptations to diverse, variable, and changing environments through time, and it is likely that many variations on such adaptations were widespread across the Indus River basin (Petrie, 2017; Petrie et al., 2017, 2018).

Our knowledge of these landscapes will only increase with further research, and it is notable that additional samples for geoarchaeological analysis and OSL dating have been collected from buried landscapes and palaeochannels in various locations across this region (Durcan et al., 2019). Significantly, it appears that the more favourable and stable landscape regimes that had existed throughout much of the earlier to mid-Holocene had begun to change by ca. $4.2 \mathrm{ka}$, when Indus civilisation settlement sites were distributed across an extensive area. In the past, the landscape was more undulating, with variable soil development on the floodplain margins and levees versus the wet alluvial zones alongside former channels. The wide floodplain areas have gradually aggraded with alluvial material, and this process continued during the post-Indus and historic periods. In combination with modern levelling activities, this process has created the ostensibly flat to gently undulating surface topography that is evident today. 


\section{ACKNOWLEDGMENTS}

This paper presents research carried out as part of the Land, Water and Settlement project (https://www.arch.cam.ac.uk/research/projects/land-water-settlement/), which was a collaboration between researchers at the University of Cambridge and Banaras Hindu University (BHU) in Varanasi. The field research was conducted with the permission of the Archaeological Survey of India. We would like to thank UK-India Educational Research Initiative for funding the $\mathrm{PhD}$ research of the first author and also supporting a number of other aspects of the Land, Water and Settlement project. Additional funding for the Land, Water and Settlement project was provided by the British Academy's Stein-Arnold Fund and the McDonald Institute for Archaeological Research. The radiocarbon dates that are reported were analysed at the Oxford Radiocarbon Accelerator Unit (ORAU, RLAHA, Oxford), with the support of several awards from NERC. The writing of this paper was made possible thanks to funding from the European Research Council under the European Union's Horizon 2020 research and innovation programme (grant agreement no. 648609) for the TwoRains project (https://www.arch.cam.ac.uk/research/projects/two-rains) and support from the DST-UKIERI programme, both of which continue the collaborative relationship between Cambridge and BHU. We would particularly like to thank A.K. Pandey from BHU and Dr. Vikas Pawar from Maharshi Dayanand University, Rohtak, for their support during the fieldwork. The laboratory analytical work was conducted in the McBurney Laboratory with particular assistance from Dr. Tonko Rajkovaca. Finally, we would like to thank Dr. Sean Taylor for reading early drafts of this paper and offering a range of helpful suggestions.

\section{SUPPLEMENTARY MATERIAL}

The supplementary material for this article can be found at https:// doi.org/10.1017/qua.2019.70

\section{REFERENCES}

Agrawal, D.P., 2007. The Indus Civilization: an Interdisciplinary Perspective. Aryan Books International, New Delhi.

Ahuja, R.L., Khanna, S.S, Garalapun, V.N, 1980. Evolution and distribution of aeolian cover in Haryana (India). Annals of Arid Zone 19, 175-182.

Amundson, R., Pendall, E., 1991. Pedology and Late Quaternary environments surrounding Harappa: a review and synthesis. In: Meadow, R. (Ed.), Harappa Excavations 1986-1990. Prehistory Press, Madison, WI, pp. 13-27.

Avery, B.W., Bascomb, C.L. (Eds.), 1974. Soil Survey Laboratory Methods. Soil Survey Technical Monograph No. 6. Rothamsted Experimental Station, Harpenden, UK.

Balbo, A.L., Rondelli, B., Conesa, F.C., Lancelotti, C., Madella, M., Ajithprasad, P., 2013. Contributions of geoarchaeology and remote sensing to the study of Holocene hunter-gatherer and agropastoral groups in arid margins. The case of North Gujarat (northwest India). Quaternary International 308-309, 53-65.

Balista, C., 1988 Evaluation of alluvial and architectural sequences at Moenjodaro through core-drilling. In: Jansen, M., Tosi, M. (Eds.), Moenjodaro: From Surface Evaluation to Ground Testing. Interim Reports, Vol. 3. Istituto Italiano per ilmedio ed Estremo Oriente, Rome, Italy; and German Research Project MohenjoDaro, RWTH, Aachen, Germany, pp. 109-134.
Belcher, W., 1997. Marine and riverine resource use during the Indus Valley tradition: a preliminary comparison of fish remains from Balakot and Harappa. In: Allchin, B., Allchin, F.R. (Eds.), South Asian Archaeology 1995. Oxford and IBH, New Delhi, pp. 173-185.

Belcher, W., 1998. Fish Exploitation of the Baluchistan and Indus Valley Traditions: An Ethnoarchaeological Approach to the Study of Fish Remains. PhD dissertation, University of Wisconsin, Madison.

Belcher, W.R., Belcher, W.R., 2000. Geologic constraints on the Harappa archaeological site, Punjab Province, Pakistan. Geoarchaeology 15, 679-713.

Berner, A., Hildermann, I., Fliessbach, A., Pfoiffner, L., Niggli, U., Mader, P., 2008. Crop yield and soil fertility response to reduced tillage under organic management. Soil and Tillage Research 101, 89-96.

Bhadra, B.K., Gupta, A.K., Sharma, J.R., 2009. Saraswati Nadi in Haryana and its linkage with the Vedic Saraswati River - integrated study based on satellite images and ground based information. Journal of the Geological Society of India 73, 273-288.

Bhan, S., 1975. Excavation at Mitathal (1968) and Other Explorations in the Sutlej-Yamuna Divide. Kurukshetra University, Kurukshetra, India.

Bhan, S., Shaffer, J.G., 1982. New discoveries in northern Haryana. Man and Environment 2, 59-68.

Bhatia, S.P., Kumar, S., 1987. Haryana District Gazetteers: Hisar. Revenue Department, Haryana Gazetteers Organisation, Chandigarh, India.

Bullock, P., Murphy, C.P., 1979. Evolution of a palaeo-argillic brown earth (Paleudalf) from Oxfordshire, England. Geoderma 22, 225-252.

Chakrabarti, D.K., 1999. India: An Archaeological History: Palaeolithic Beginnings to Early Historic Foundations. Oxford University Press, Oxford.

Chakrabarti, D.K., Saini, S., 2009. The Problem of the Sarasvati River and Notes on the Archaeological Geography of Haryana and Indian Panjab. Aryan Books, New Delhi.

Clark, A., 1996. Seeing beneath the Soil: Prospecting Methods in Archaeology. 2nd ed. Routledge, London.

Clift, P.D., Carter, A.C., Giosan, L., Durcan, J.A., Duller, G.A.T., Macklin, M.G., Alizai, A., et al., 2012. U-Pb Zircon dating evidence for a Pleistocene Sarasvati river and capture of the Yamuna River. Geology 40, 211-214.

Conesa, F.C., Devanthéry, N., Balbo, A.L., Madella, M., Monserrat, O., 2014. Use of satellite SAR for understanding long-term human occupation dynamics in the monsoonal semiarid plains of North Gujarat, India. Remote Sensing 6, 11420 11443.

Conesa, F.C., Lobo, A., Alcaina, J., Balbo, A.L., Madella, M., Rajesh, S.V., Ajithprasad, P., 2017. Multi-proxy survey of openair surface scatters in drylands: archaeological and physicochemical characterization of fossilised dunes in North Gujarat (India). Quaternary International 436, 57-75.

Conesa, F.C., Madella, M., Galiatsatos, N., Balbo, A.L., Rajesh, S.V., Ajithprasad, P., 2015. CORONA photographs in monsoonal semi-arid environments: addressing archaeological surveys and historic landscape dynamics over North Gujarat, India. Archaeological Prospection 22, 75-90.

Courty, M.A., 1985. Le milieu physique et utilisations du sol. In: Francfort, H.-P. (Ed.), Prospections Archéologiques au Nord-Ouest de l'Inde: Rapport Préliminaire 1983-1984. Éditions Recherche sur les Civilisations, Mémoire No. 62; Travaux 
de la Mission Archéologique Française en Inde No. 1. Éditions Recherche sur les Civilisations, Paris, pp. 11-31.

Courty, M.A., 1990. Pedogenesis on Holocene calcareous parent materials under semi-arid conditions (Ghaggar Plain, Nw India). In: Douglas, L.A. (Ed.), Soil Micro-morphology: A Basic and Applied Science. Developments in Soil Science, Vol. 19. Elsevier, Amsterdam, pp. 361-366.

Courty, M.A., 1995. Late Quaternary environmental changes and natural constraints to ancient land use (northwest India). In: Johnson, E. (Ed.), Ancient Peoples and Landscapes. Museum of Texas Technical University, Lubbock, TX, pp. 105-126.

Courty, M.A., Dhir, P., Raghavan, H., 1987. Microfabrics of calcium carbonate accumulations in arid soils of western India. In: Soil Micromorphology: Proceedings of the VIIth International Working Meeting on Soil Micromorphology, Paris, July 1985. Association Française pour l'Étude du Sol, Paris, pp. 227-234.

Courty, M.A., Fedoroff, N., 1985. Micromorphology of recent and buried soils in a semi-arid region of northwestern India. Geoderma 35, 287-332.

Courty, M.A., Goldberg, P., Macphail, R., 1989. Soils and Micromorphology in Archaeology. Cambridge University Press, Cambridge.

Cucarzi, M., 1984. Geophysical investigations at Moenjo Daro: preliminary report. In: Jansen, M., Urban, G. (Eds.), Reports on Field Work Carried out at Mohenjo-Daro Pakistan 1982-83 by the IsMEO-Aachen-University Mission. Interim Reports, Vol. 1. German Research Project Mohenjo-Daro, RWTH, Aachen, Germany, pp. 191-200.

Cucarzi, M., 1987. A model of morphogenesis for Mohenjodaro. In: Jansen, M., Urban, G. (Eds.), Reports on Field Work Carried out at Mohenjo-Daro Pakistan 1983-84 by the IsMEO-Aachen-University Mission. Interim Reports Vol. 2. German Research Project Mohenjo-Daro, RWTH, Aachen, Germany, pp. 79-90.

Dangi, V., 2009. Archaeology of the Ghaggar Basin: settlement archaeology of Meham Block, Rohtak, Haryana, India. In: Osada, T., Uesugi, A. (Eds.), Occasional Paper 8: Linguistics, Archaeology and the Human Past. Research Institute for Humanity and Nature, Kyoto, Japan, pp. 1-111.

Dangi, V., 2011. Explorations along the Ghaggar River and Sirhind Nala in Haryana and Punjab. Man and Environment 36, 66-87.

Danino, M., 2010. The Lost River: On the Trail of the Saraswati. Penguin, New Delhi.

Dixit, Y., Hodell, D.A., Giesche, A., Tandon, S.K., Gázquez, F., Saini, H.S., Skinner, L., et al., 2018. Intensified Indian summer monsoon and the urbanization of the Indus civilization in northwest India. Scientific Reports 8, 4225.

Dixit, Y., Hodell, D.A., Petrie, C.A., 2014a. Abrupt weakening of the summer monsoon in northwest India $\sim 4100 \mathrm{yr}$ ago. Geology 42, 339-342.

Dixit, Y., Hodell, D.A., Sinha, R., Petrie, C.A., 2014b. Abrupt weakening of the Indian summer monsoon at $8.2 \mathrm{kyr}$ B.P. Earth and Planetary Science Letters 391, 16-23.

Duller, G.A.T., 2003. Distinguishing quartz and feldspar in single grain luminescence measurements. Radiation Measurements 37, 161-165.

Durand, N., Monger, H.C., Canti, M.G., 2010. Calcium carbonate features. In: Stoops, G., Marcelino, V., Mees, F. (Eds.), Interpretation of Micromorphological Features of Soils and Regoliths. Elsevier, Amsterdam, pp. 149-194.

Durcan, J.A., Duller, G.A.T., 2011. The fast ratio: a rapid measure for testing the dominance of the fast component in the initial OSL signal from quartz. Radiation Measurements 46, 1065-1072.
Durcan, J.A., King, G.E., Duller, G.A.T., 2015. DRAC: dose rate and age calculator for trapped charge dating. Quaternary Geochronology 28, 54-61.

Durcan, J.A., Thomas, D.S.G., Gupta, S., Pawar, V., Singh, R.N., Petrie, C.A., 2019. Holocene landscape dynamics in the Ghaggar-Hakra palaeochannel region at the northern edge of the Thar Desert northwest India. Quaternary International 501B, 317-327.

Fedoroff, N., 1968. Genese et morphologie des sols a horizon b textural en France atlantique. Science du Sol 1, 29-65.

Fedoroff, N., 1972. Clay illuviation. In: Soil Micromorphology: Proceedings of the 3rd International Working Meeting on Soil Micromorphology. Państwowe Wydawnictwo Naukowe, Warsaw, Poland, pp. 195-207.

Flam, L., 1981. The Palaeogeography and Prehistoric Settlement Patterns in Sind, Pakistan (ca. 4000-2000 B.C.). University Microfilms International, Ann Arbor, MI.

Flam, L., 1993. Fluvial geomorphology of the lower Indus Basin (Sindh, Pakistan) and the Indus civilisation. In: Shroder, J.F. (Ed.), Himalaya to the Sea: Geology, Geomorphology and the Quaternary. Routledge, Abingdon, Oxfordshire, UK, pp. 22652287.

Flam, L., 1999. Ecology and population mobility in the prehistory settlement of the lower Indus Valley, Sindh, Pakistan. In: Meadows, A., Meadows, P.S. (Eds.), The Indus River: Biodiversity, Resources, Humankind. Oxford University Press, Oxford, pp. 313-323.

Flam, L., 2013. The Sindh Archaeological Project: explorations in the lower Indus Basin and western Sindh. In: Abraham, S.A., Gullapalli, P., Raczek, T.P., Rizvi, U.Z. (Eds.), Connections and Complexity: New Approaches to the Archaeology of South Asia. Left Coast Press, Walnut Creek, CA, pp. 91-106.

Fraser, I.S., 1958. Report on a Reconnaissance Survey of the Landforms, Soils and Present Land Use of the Indus Plains, West Pakistan. Colombo Plan Cooperative Project, Toronto.

French, C., 2003. Geoarchaeology in Action: Studies in Soil Micromorphology and Landscape Evolution. Routledge, London.

French, C., 2015. A Handbook of Geoarchaeological Approaches to Settlement Sites and Landscapes. Oxbow Books, Oxford, UK.

French, C.A.I., Sulas, F., Petrie, C.A., 2017. Expanding the research parameters of geoarchaeology: case studies from Aksum in Ethiopia and Haryana in India. Archaeological and Anthropological Sciences 9, 1613-1626.

Galbraith, R.F., Roberts, R.G., Laslett, G.M., Yoshida, H., Olley, J.M., 1999. Optical dating of single and multiple grains of quartz from Jinmium rock shelter, northern Australia: part I, experimental design and statistical models. Archaeometry 41, 339-364.

Geyh, M.A., Ploethner, D., 1995. An applied palaeohydrological study in Cholistan, Thar Desert, Pakistan. In: Adar, E.M., Leibundgut, C. (Eds.), Application of Tracers in Arid Zone Hydrology: Proceedings of an International Symposium held at Vienna, 22-26 August 1994. IAHS Publication No. 232. International Association of Hydrological Sciences, Wallingford, UK, pp. 119-127.

Ghose, B., Kar, A., Hussain, Z., 1979. The lost courses of the Saraswati River in the Great Indian Desert: new evidence from Landsat Imagery. Geographical Journal 145, 446-451.

Ghosh, A., 1958. Excavations at Alamgirpur. In: Ghosh, A. (Ed.), Indian Archaeology 1958-59-A Review. Department of Archaeology, Government of India, New Delhi, pp. 51-52. 
Gibling, M., Tandon, S., Sinha, R., Jain, M., 2005. Discontinuitybounded alluvial sequences of the southern Gangetic Plains, India: aggradation and degradation in response to monsoonal strength. Journal of Sedimentary Research 75, 369-385.

Giesche, A., Staubwasser, M., Petrie, C.A., Hodell, D.A., 2019. Indian winter and summer monsoon strength over the $4.2 \mathrm{ka} \mathrm{BP}$ event in foraminifer isotope records from the Indus River delta in the Arabian Sea. Climate of the Past 15, 73-90.

Giosan, L., Clift, P.D., Macklin, M.G., Fuller, D.Q., Constantinescu, S., Durcan, J.A., Stevens, T., et al., 2012. Fluvial landscapes of the Harappan civilisation. Proceedings of the National Academy of Sciences of the United States of America 109, E1688-E1694.

Goldberg, P., Macphail, R., 2006. Practical and Theoretical Geoarchaeology. Blackwell, Oxford, UK.

Green, A.S., Petrie, C.A., 2018. Landscapes of urbanisation and de-urbanization: integrating site location datasets from northwest India to investigate changes in the Indus civilization's settlement distribution. Journal of Field Archaeology 43, 284-299.

Greenman, D.W., Swarzenski, W.V., Bennett, G.D., 1967. GroundWater Hydrology of the Punjab, Pakistan, with Emphasis on Problems Caused by Canal Irrigation. Water Supply Paper 1608-H. U.S. Geological Survey, Washington, DC.

Guerin, G., Mercier, N., Adamiec, G., 2011. Dose-rate conversion factors: update. Ancient TL 29, 5-8.

Gupta, A.K., Sharma, J.R., Sreenivasan, G., 2011. Using satellite imagery to reveal the course of an extinct river below the Thar Desert in the Indo-Pak region. International Journal of Remote Sensing 32, 5197-5216.

Gupta, A.K., Sharma, J.R., Sreenivasan, G., Srivastava, K.S., 2004. New finding on the course of river Saraswati. Journal of the Indian Society of Remote Sensing 32, 1-24.

Harvey, M.D., Schumm, S.A., 1999. Indus River dynamics and the abandonment of Mohenjo Daro. In: Meadow, A., Meadows, P.S. (Eds.), The Indus River: Biodiversity, Resources, Humankind. Oxford University Press, Karachi, Pakistan, pp. 333-348.

Hillel, D. (Ed.), 2004. Encyclopedia of Soils in the Environment. Academic Press, Amsterdam.

IUSS Working Group WRB, 2014. World Reference Base for Soil Resources 2014. World Soil Resources Reports No. 106. Food and Agriculture Organization of the United Nations, Rome, Italy.

Jacobs, Z., Wintle, A.G., Duller, G.A.T., 2003. Optical dating of dune sand from Blombos Cave, South Africa: I - multiple grain data. Journal of Human Evolution 44, 599-612.

Jansen, M., 1999. Mohenjo Daro and the river Indus. In: Meadow, A. and Meadows, P.S. (Eds.), The Indus River: Biodiversity, Resources, Humankind. Oxford University Press, Karachi, Pakistan, pp. 349-383.

Jones, R., 1999. Dating the human colonization of Australia: radiocarbon and luminescence revolutions. Proceedings of the British Academy 99, 37-65.

Jorgensen, D.W., Harvey, M.D., Schumm, S.A., Flam, L., 1993. Morphology and dynamics of the Indus River: implications for the Mohenjo-daro site. In: Schroder, J.F, Jr. (Ed.), Himalaya to the Sea: Geology, Geomorphology and the Quaternary. Routledge, New York, pp. 288-326.

Joshi, J.P., Bala, M., Ram, J., 1984. The Indus civilization: a reconsideration on the basis of distributional maps. In: Lal, B.B., Gupta, S.P. (Eds.), Frontiers of the Indus Civilization. Books and Books, New Delhi, pp. 511-530.

Kenoyer, J.M., 1998. Ancient Cities of the Indus Valley Civilisation. Oxford University Press, Oxford.
Kooistra, M.J., 1982. Micromorphological Analysis and Characterization of 70 Benchmark Soils of India. A Basic Reference. Netherlands Soil Survey Institute, Wageningen, the Netherlands.

Kottek, M., Grieser, J., Beck, C., Rudolf, B., Rubel, F., 2006. World map of the Köppen-Geiger climate classification updated. Meteorologische Zeitschrift 15, 259-263.

Kühn, P., Aguilar, J., Miedema, R., 2010. Textural pedofeatures and related horizons. In: Stoops, G., Marcelino, V., Mees, F. (Eds.), Interpretation of Micromorphological Features of Soils and Regoliths. Elsevier, Amsterdam, pp. 217-250.

Kumar, M., 2009. Harappan settlements in the Ghaggar-Yamuna Divide. In: Osada, T., Uesugi, A. (Eds.), Occasional Paper 7: Linguistics, Archaeology and the Human Past. Indus Project, Research Institute for Humanity and Nature, Kyoto, Japan, pp. 1-75.

Lal, B.B., 1997. The Earliest Civilisation of South Asia. Aryan Books International, New Delhi.

Lal, B.B., 2002. The Sarasvati Flows On: the Continuity of Indian Culture. Aryan Books International, New Delhi.

Lambrick, H., 1967. The Indus flood-plain and the 'Indus' civilization. Geographical Journal 133, 483-495.

Leonardi, G., 1988. New problems of surface archaeology: sampling in HR east area of Moenjodaro (Pakistan). In: Jansen, M., Tosi, M. (Eds.), Moenjodaro: From Surface Evaluation to Ground Testing. Interim Reports, Vol. 3. Istituto Italiano per ilmedio ed Estremo Oriente, Rome, Italy; and German Research Project Mohenjo-Daro, RWTH, Aachen, Germany, pp. 7-94.

Lindbo, D.L., Stolt, M.H., Vepraskas, M.J., 2010. Redoximorphic features. In: Stoops, G., Marcelino, V., Mees, F. (Eds.), Interpretation of Micromorphological Features of Soils and Regoliths. Elsevier, Amsterdam, pp. 129-147.

Madella, M., Fuller, D.Q., 2006. Palaeoecology and the Harappan civilisation of South Asia: a reconsideration. Quaternary Science Reviews 25, 1283-1301.

Meadows, A., Meadows, P.S. (Eds.), 1999. The Indus River: Biodiversity, Resources, Humankind. Oxford University Press, Karachi, Pakistan.

Mithal, R.S., 1968. The physiographical and structural evolution of the Himalaya. In: Law, B.C. (Ed.), Mountains and Rivers of India. National Committee for Geography, Calcutta, India, pp. 41-81.

Moody, L.E., 2006. Leaching and illuviation. In: Lal, R. (Ed.), Encyclopedia of Soil Science. Vol. 10. Marcel Dekker, New York, pp. 1022-1025.

Mughal, M.R., 1997. Ancient Cholistan: Archaeology and Architecture. Ferozsons, Lahore, Pakistan.

Murphy, C.P., 1986. Thin Section Preparation of Soils and Sediments. AB Academic, Berkhamsted, UK.

Murray, A.S., Wintle, A.G., 2000. Luminescence dating of quartz using an improved single-aliquot regenerative-dose protocol. Radiation Measurements 32, 57-73.

Nath, A., 1998. Rakhigarhi: a Harappan metropolis in the Saraswati-Drishadwati divide. Puratattva 28, 39-45.

Oldham, C.F. 1874. Notes on the Lost River of the Indian Desert. Calcutta Review 59, 1-27.

Oldham, C.F., 1893. The Sarasvati and the lost river of the Indian Desert. Journal of the Royal Asiatic Society 25, 49-76.

Oldham, R.D. 1886. On probably changes in the geography of the Punjab and its rivers: an historico-geographical study. Journal of Asiatic Society of Bengal 55, 322-343

Orengo, H.A., Petrie, C.A., 2017. Large-scale, multi-temporal remote sensing of palaeo-river networks: a case study from northwest India and its implications for the Indus civilisation. Remote Sensing 9, 735 . 
Orengo, H.A., Petrie, C.A., 2018. Multi-scale relief model (MSRM): a new algorithm for the analysis of subtle topographic change in digital elevation models. Earth Surface Processes and Landforms 43, 1361-1369.

Parikh, D., Petrie, C.A., 2016. Urban-rural dynamics and Indus ceramic production in northwest India: a preliminary analysis of the pottery from Masudpur I and Masudpur VII. In: Lefèvre, V., Didier, A., Mutin, B. (Eds.), South Asian Archaeology 2012: Man and Environment in Prehistoric and Protohistoric South Asia: New Perspectives. Indicopleustoi 12. Brepols, Turnhout, Belgium, pp. 221-241.

Parikh, D., Petrie, C.A., 2019. 'We are inheritors of a rural civilisation': rural complexity and the ceramic economy in the Indus civilisation in northwest India. World Archaeology 2019, 1-21.

Parmar, N., Sharan, A., Pawar, V., Kumar, V., 2013. Harappan settlement system and economic status in the semi-arid zone, Bhiwani District, Haryana. Heritage Journal of Multidisciplinary Studies in Archaeology 1, 515-538.

Pascoe, E.H., 1920. The early history of the Indus, Brahmaputra, and Ganges. Quarterly Journal of the Geological Society of London 75, 138-157.

Pawar, V., Parmar, N., Sharan, A., 2013. Harappan civilization: emerging picture in Hanumangarh District, Rajasthan. Heritage Journal of Multidisciplinary Studies in Archaeology 1, 475-485.

Petrie, C.A., 2013. South Asia. In: Clark, P. (Ed.), The Oxford Handbook of Cities in World History. Oxford University Press, Oxford.

Petrie, C.A., 2017. Crisis, what crisis? Adaptation, resilience and transformation in the Indus Civilisation, In: Cunningham, T., Driessen, J. (Eds.), Crisis to Collapse: The Archaeology of Social Breakdown. Presses Universitaires de Louvain, Louvain-laNeuve, Belgium, pp. 43-64.

Petrie, C.A., Bates, J., 2017. 'Multi-cropping,' intercropping and adaptation to variable environments in the Indus civilisation, Journal of World Prehistory 30, 81-130.

Petrie, C.A, Bates, J., Dixit, Y., French, C., Hoddell, D., Jones, P., Lancelloti, C., et al., 2017. Adaptation to variable environments, resilience to climate change: investigating Land, Water and Settlement in Indus northwest India. Current Anthropology 58, 1-30.

Petrie, C.A., Bates, J., Higham, T., Singh, R.N., 2016. Feeding ancient cities in South Asia: dating the adoption of rice, millet and tropical pulses in the Indus civilisation. Antiquity 90, 1489-1504.

Petrie, C.A., Parikh, D., Green, A.S., Bates, J., 2018. Looking beneath the veneer: thoughts about environmental and cultural diversity in the Indus civilisation. In: Frenez, D., Jamison, G., Law, R., Vidale, M., Meadow, R.H. (Eds.), Walking with the Unicorn. Social Organization and Material Culture in Ancient South Asia. Archaeopress, Oxford, UK, pp. 455-476.

Petrie, C.A., Singh, R., Singh, A., 2009. Investigating changing settlement dynamics on the plains: the 2009 survey and excavations at Masudpur (Hissar District, Haryana). Puratattva 39, 38-52.

Petrie, C.A., Thomas, K.D., 2012. The topographic and environmental context of the earliest village sites in western South Asia. Antiquity 86, 1055-1067.

Petrie, C.A., Weeks, L.R., 2019. The Iranian Plateau and the Indus River basin. In: Chiotis, E. (Ed.), Climate Changes in the Holocene: Their Impacts and Human Adaptation. Taylor and Francis, Boca Raton, FL, pp. 291-322.

Pilgrim, G.E., 1919. Suggestions concerning the history of the drainage of northern India arising out of the study of the Siwalik boulder conglomerates. Journal of the Asiatic Society of Bengal $15,81-99$.
Possehl, G., 1999. Indus Age: The Beginnings. University of Pennsylvania Press, Philadelphia.

Possehl, G., 2002. The Indus Civilization: A Contemporary Perspective. Altamira Press, Walnut Creek, CA.

Raikes, R., 1964. The end of the ancient cities of the Indus. American Anthropologist 66, 284-299.

Raikes, R., 1967. Kalibangan: death from natural causes. Antiquity 42, 286-291.

Raikes, R., Dales, G., 1986. Reposte to Wasson's sedimentological basis of the Mohenjo Daro flood hypothesis. Man and Environment 10, 33-44.

Rajani, M.B., Rajawat, A.S., 2011. Potential of satellite based sensors for studying distribution of archaeological sites along palaeo channels: Harappan sites a case study. Journal of Archaeological Science 38, 2010-2016.

Ramasamy, S.M., Bakliwal, P.C., Verma, R.P., 1991. Remote sensing and river migration in western India. International Journal of Remote Sensing 12, 2597-2609.

Retallack, G., 1990. Soils of the Past. Unwyn Hyman, London.

Saini, H., Tandon, S., Mujtaba, S., Pant, N., Khorana, R., 2009. Reconstruction of buried channel-floodplain systems of the northwestern Haryana Plains and their relation to the 'Vedic' Saraswati. Current Science 97, 1634-1643.

Schroder, J.F. (Ed.), 1993. Himalaya to the Sea: Geology, Geomorphology and the Quaternary. Routledge, Abingdon, Oxfordshire, UK.

Schuldenrein, J., 2002. Geoarchaeological perspectives on the Harappan sites of South Asia. Indian Archaeology in Retrospect: Protohistory: Archaeology of the Harappan Civilization 2, 47-80.

Schuldenrein, J., Wright, R., Khan, M., 2007. Harappan geoarchaeology reconsidered: Holocene landscapes and environments of the greater Indus plain. In: Stone, E. (Ed.), Settlement and Society: Essays Dedicated to Robert McCormick Adams. Cotsen Institute of Archaeology, University of California, Los Angles, pp. 83-116.

Schuldenrein, J., Wright, R., Mughal, M., Khan, M., 2004. Landscapes, soils, and mound histories of the Upper Indus Valley, Pakistan: new insights on the Holocene environments near ancient Harappa. Journal of Archaeological Science 31, 777-797.

Sharan, A., Pawar, V., Parmar, N., 2013. An archaeological reconnaissance of the proto-historic settlements in Mansa District, Punjab. Heritage Journal of Multidisciplinary Studies in Archaeology 1, 500-514.

Shinde, V., Green, A.S., Parmar, N., Sable, P.D., 2013. Rakhigarhi and the Harappan civilization: recent work and new challenges. Bulletin of the Deccan College Research Institute 72/73, 43-53.

Shinde, V.S., Kim, Y.J., Woo, E.J., Jadhav, N., Waghmare, P., Yadav, Y., Munshi, A., et al., 2018. Archaeological and anthropological studies on the Harappan cemetery of Rakhigarhi, India. PLoS ONE 13, e0192299.

Singh, A., Thomsen, K.J., Sinha, R., Buylaert, J.-P., Carter, A., Mark, D.F., Mason, P.J., et al., 2017. Counter-intuitive influence of Himalayan river morphodynamics on Indus civilisation urban settlements. Nature Communications 8, 1617.

Singh, I.B., 1996. Geological evolution of Ganga Plain-an overview. Journal of the Palaeontological Society of India 41, 99-137.

Singh, R.N., Green, A.S., Green, L.M., Ranjan, A., Alam, A., Petrie, C.A., 2018. Between the hinterlands: preliminary results from the TwoRains survey in northwest India 2017. Man and Environment 43, 84-102.

Singh, R.N., Petrie, C.A., French, C.A., Bates, J., Pandey, A.K., Parikh, D., Lancelotti, C., Redhouse, D.I., 2012. Survey and 
excavations at Dabli-vas Chugta, Hanumangarh District, Rajasthan, Puratattva 42, 133-147.

Singh, R.N., Petrie, C.A., French, C.A.I., Goudie, A.S., Gupta, S., Tewari, R., Singh, A.K., et al., 2008. Settlements in context: reconnaissance in western Uttar Pradesh and Haryana, April and May 2008. Man and Environment 33, 71-87.

Singh, R.N., Petrie, C.A., French, C.A., Neogi, S., Pandey, A.K., Parikh, D., Pawar, V., 2010a. Geoarchaeological survey and excavations at Burj, Fatehabad, Haryana, Puratattva 40, 94-101.

Singh, R.N., Petrie, C.A., Joglekar, P., Neogi, S., Lancelotti, C., Pandey, A. K., Pathak, A., 2013. Recent excavations at Alamgirpur, Meerut District: a preliminary report. Man and Environment $38,32-54$

Singh, R.N., Petrie, C.A., Pawar, V., Pandey, A.K., Neogi, S., Singh, M., Singh, A.K., Parikh, D., Lancelotti, C., 2010 b. Changing patterns of settlement in the rise and fall of Harappan urbanism: preliminary report on the Rakhigarhi Hinterland Survey 2009. Man and Environment 35, 37-53.

Singh, R.N., Petrie, C.A., Pawar, V., Pandey, A., Parikh, D., 2011. New insights into settlement along the Ghaggar and its hinterland: a preliminary report on the Ghaggar Hinterland Survey 2010. Man and Environment 36, 89-106.

Singh, R.N., Petrie, C.A., Neogi, S., Pawar, V., Pandey, A., Parikh, D., Parmar, N., Singh, A.K., 2015a. Excavations at Masudpur I (Sampolia Khera), District Hissar. In: Tewari, R., Dimri, D.N. (Eds.), Indian Archaeology 2008-09-A Review. Archaeological Survey of India, New Delhi, pp. 57-61.

Singh, R.N., Petrie, C.A., Neogi, S., Pawar, V., Pandey, A., Parikh, D., Parmar, N., Singh, A.K., 2015b. Excavations at Masudpur VII (Bhimwada Jodha), District Hissar. In: Tewari, R., Dimri, D.N. (Eds.), Indian Archaeology 2008-09A Review. Archaeological Survey of India, New Delhi, pp. 61-71.

Singh, R.N., Petrie, C.A., Singh, A.K., Singh, M., 2009. Excavations at Masudpur (Hissar District, Haryana) - 2009: a preliminary report. Bhāratī 33, 35-49.

Srivastava, P., Parkash, B., 2002. Polygenetic soils of the northcentral part of the Gangetic Plains: a micromorphological approach. Catena 46, 243-259.
Stein, M.A., 1942. A survey of ancient sites along the "Lost" Sarasvari River. Geographical Journal 99, 173-182.

Stolt, M.H., Lindbo, D.L., 2010. Soil organic matter. In: Stoops, G., Marcelino, V., Mees, F. (Eds.), Interpretation of Micromorphological Features of Soils and Regoliths. Elsevier, Amsterdam, pp. 369-396.

Valdiya, K.S., 2002. Saraswati: The River That Disappeared. Universities Press, Hyderabad, India.

van Dijk, W.M., Densmore, A.L., Singh, A., Gupta, S., Sinha, R., Mason, P.J., Joshi, S.K., et al., 2016. Linking the morphology of fluvial fan systems to aquifer stratigraphy in the Sutlej-Yamuna plain of northwest India. Journal of Geophysics Research: Earth Surface 121, 201-222.

Weber, J., Karczewska, A., Drozd, J., Licznar, M., Licznar, S., Jamroz, E., Kocowicz, A., 2007. Agricultural and ecological aspects of a sandy soil as affected by the application of solid waste composts. Soil Biology and Biochemistry 39, 1294-1302.

Wheeler, R.E.M., 1968. The Indus Civilization: Supplementary Volume to the Cambridge History of India. Cambridge University Press, Cambridge.

Wieder, M., Yaalon, D.H.H., 1978. Grain cutans for clay illuviation in calcareous soil material. In: Delgado, M. (Ed.), Micromoforlogia de Suelos. Grenada, pp. 1133-1158.

Wilkinson, T.J., 2003. Archaeological Landscapes on the Near East. University of Arizona Press, Tucson,

Wright, R.P., 2010. The Ancient Indus: Urbanism, Economy, and Society. Case Studies in Early Societies. Cambridge University Press, Cambridge.

Wright, R.P., Hritz, C., 2013. Satellite remote sensing imagery: new evidence for site distributions and ecologies in the upper Indus. In: Frenez, D., Tosi, M. (Eds.), South Asian Archaeology 2007. BAR International Series 2454. Archaeopress, Oxford, pp. 315-321.

Wright, R.P., Bryson, R.A., Schuldenrein, J. 2008. Water supply and history: Harappa and the Beas regional survey. Antiquity 82, 37-48.

Yashpal, Sahai, B. SoodR.K., Agrawal, D.P., 1980. Remote sensing of the 'lost' Saraswati River. Proceedings of the Indian Academy of Science 89, 313-331. 